\title{
Role of Wireless Aided Technologies in the Solid Waste Management: A Comprehensive Review
}

\author{
Shaik Vaseem Akram ${ }^{1}\left(\mathbb{D}\right.$, Rajesh Singh ${ }^{1}{ }^{(0)}$, Anita Gehlot ${ }^{1}$, Mamoon Rashid ${ }^{2, *} \mathbb{C}^{\circ}$, Ahmed Saeed AlGhamdi $^{3} \mathbb{D}$, \\ Sultan S. Alshamrani ${ }^{4}$ and Deepak Prashar ${ }^{5}$ (D) \\ 1 School of Electronics and Electrical Engineering, Lovely Professional University, Jalandhar 144411, India; \\ vaseem.11814442@lpu.in (S.V.A.); rajesh.23402@lpu.co.in (R.S.); anita.23401@lpu.co.in (A.G.) \\ 2 Department of Computer Engineering, Faculty of Science and Technology, Vishwakarma University, \\ Pune 411048, India \\ 3 Department of Computer Engineering, College of Computer and Information Technology, Taif University, \\ P.O. Box 11099, Taif 21994, Saudi Arabia; asjannah@tu.edu.sa \\ 4 Department of Information Technology, College of Computer and Information Technology, Taif University, \\ P.O. Box 11099, Taif 21944, Saudi Arabia; susamash@tu.edu.sa \\ 5 School of Computer Science and Engineering, Lovely Professional University, Jalandhar 144411, India; \\ deepak.prashar@lpu.co.in \\ * Correspondence: mamoon.rashid@vupune.ac.in; Tel.: +91-781-434-6505
}

check for

updates

Citation: Akram, S.V.; Singh, R.; Gehlot, A.; Rashid, M.; AlGhamdi, A.S.; Alshamrani, S.S.; Prashar, D. Role of Wireless Aided Technologies in the Solid Waste Management: A Comprehensive Review. Sustainability 2021, 13, 13104. https://doi.org/ $10.3390 /$ su132313104

Academic Editors: Jorge Cristóbal and María Margallo

Received: 16 October 2021

Accepted: 23 November 2021

Published: 26 November 2021

Publisher's Note: MDPI stays neutral with regard to jurisdictional claims in published maps and institutional affiliations.

Copyright: (c) 2021 by the authors. Licensee MDPI, Basel, Switzerland. This article is an open access article distributed under the terms and conditions of the Creative Commons Attribution (CC BY) license (https:/ / creativecommons.org/licenses/by/ $4.0 /)$.

\begin{abstract}
Currently, a smart city is an emerging field in urban cities to improve the quality of life through information and communication technology (ICT). In general, the traditional solid waste management (SWM) approach taken by municipal authorities for waste collection in urban areas must be enhanced to achieve the green and smart city goals. This article is primarily focused on the progress of ICT technologies in solid waste management. With that aim, a thorough analysis is carried out in the article, and from the analysis, we have identified distinct ICT technologies that have been implemented in SWM. The function, application, and limitations of each technology are presented in the article. From the review, it is concluded that the implementation of the Internet of Things (IoT) plays a significant role in minimizing the negative impact of waste on the environment. It is also identified that selection of the appropriate wireless communication protocol is critical during the implementation of IoT-based system because the sensor node at the bins is batterypowered. In addition, it is analysed that blockchain technology plays an essential role in realizing the waste-money model, as this model includes transactions between users and recyclers. Finally, in this article, we propose that the waste-to-money model, local network and gateway architecture, vision node, and customized prototype improve solid waste management system in terms of communication, energy consumption, and real-time monitoring.
\end{abstract}

Keywords: blockchain; SWM; ICT; IoT; vision node

\section{Introduction}

According to United Nations, $66 \%$ of the global population will be living in urban cities by 2025 in comparison to $54 \%$ currently inhabiting urban cities. It also reports that the consumption of material in cities will be accelerated to nearly 90 billion tonnes by 2050, contrasted to 40 billion tonnes in 2010 [1]. According to World Bank research [2], 4.3 billion urban inhabitants will generate 2.2 billion tonnes of solid trash annually by 2025 . The report reveals that high-income people are generating a larger quantity of waste than low-income [3]. The Indian planning commission report reveals that in 2014, the waste generated by India was 62 million tonnes (MT). It is projected that, by the year 2051, the population of India will be 1.82 billion, and the population of urban India will reach nearly $50 \%$ of the total population [4]. Considering the rise in the population, the waste will be increasing by $5 \%$ per year. Therefore, by 2047 , the waste generated will be around 260 million tonnes per annum. To dump this amount of waste, around $1400 \mathrm{sq} . \mathrm{km}$ area 
will be required [5]. In India, only $70 \%$ of waste is collected, and the remaining $30 \%$ is amalgamated with other debris or lost in the environment [3]. Only $12.45 \%$ of the garbage collected is managed, and the remaining is dumped in landfills, causing soil deterioration, groundwater contamination, and air pollution. Urban local bodies in our country spend more than $70 \%$ of their budget only for collecting waste, and the remaining amount $30 \%$ is utilized for transport [6]. Moreover, the sustainable development goals (SDGs) for waste management set a target of sustainable management of waste to ensure protection of public health and environment [7]. The challenges for solid waste management (SWM) indicate the immediate need for necessary action for upgrading the services of waste management authorities especially in middle- and low-income countries [8] Solid waste is unusable solid material generated by human activities in residential, industrial, or commercial sites. It is generated either as the product of manufacturing processes or as a result of things or materials being disposed of after consumption in the domestic or commercial domains. Figure 1 illustrates distinct kinds of solid waste categorized based on hazardous and nonhazardous. Organic waste, agriculture waste, and plastic waste fall under non-hazardous waste. The composition of waste is vital for implementing waste management life cycles including collection, transportation, recycling, and disposal [9]. It also plays a crucial role in greenhouse gas emissions [10]. Industrial waste, E-waste, nuclear waste, and bio-medical waste are hazardous waste. The waste composition differs from one country to another country and from one municipality to another municipality, urbanization, income level, and government regulations [11,12].

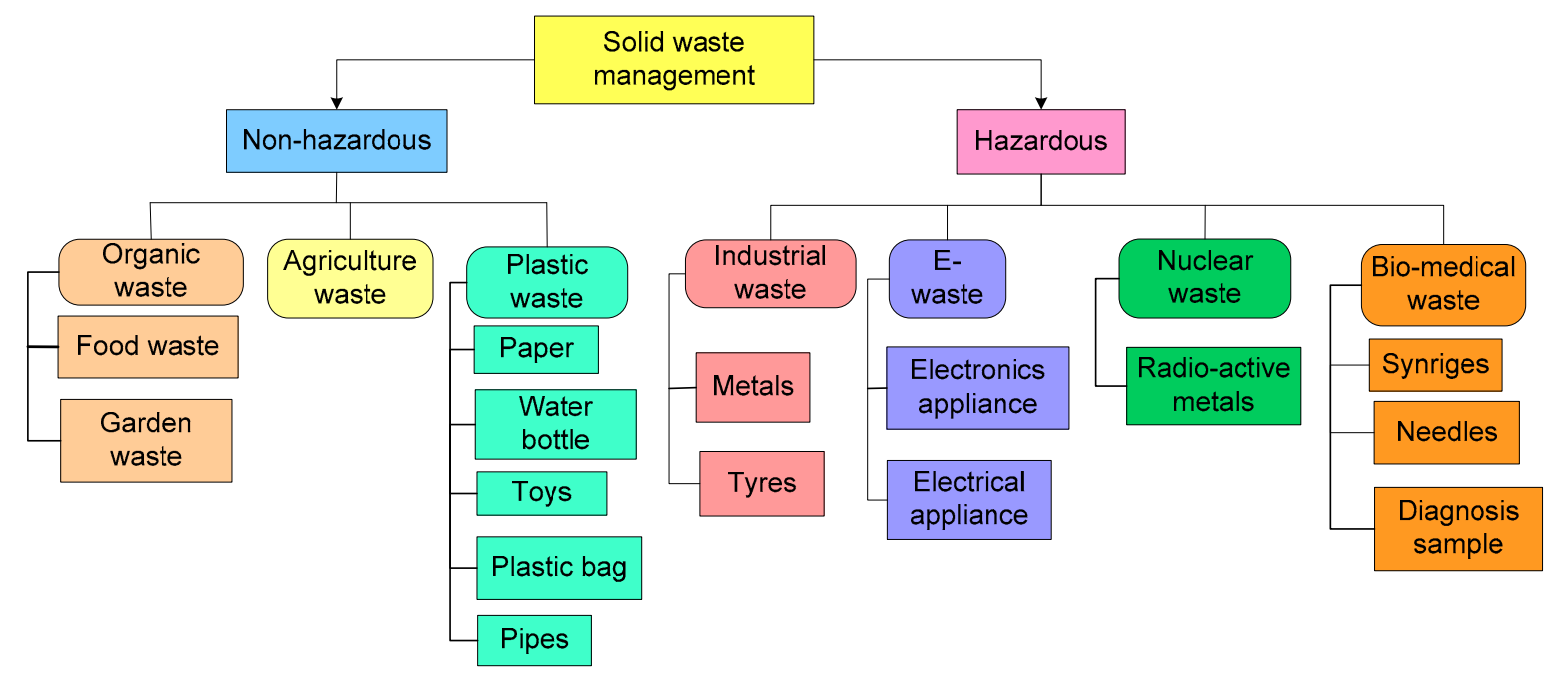

Figure 1. Types of Solid Waste.

According to the Press Information Bureau, 2016 [13], the composition of India's waste is classified into three categories: recyclable waste, organic waste, and hazardous waste. Organic waste comprises food, paper, wood, etc. Organic waste is the highest generating waste in India (Figure 2). E-waste (electronic waste) and plastic waste are categorized as recyclable waste. Organic waste is waste generated from the residents and food restaurants [14]. Organic waste from the residents and food restaurants is managed by the local municipal body. Recyclable waste is waste in which the waste is transformed into new material. Hazardous waste is a waste that has the properties of causing damage to human health or the atmosphere. Hazardous waste is produced from the industrial manufacturing process of waste to battery trash, or it can take several forms, including liquids and liquid gases [15]. Bio-medical is waste from the hospital environment such as syringes, needles, diagnosis samples, drugs, medical devices, etc. This waste is infectious and can spread infectious diseases [16]. Ineffectual supervision of organic waste results in the creation of airborne disease in an open environment, which leads to contamination of water bodies and generates harmful gases due to burning $[17,18]$. 
Solid Waste Management is required for achieving sustainable metropolitan development by collecting, transporting, and recycling the solid waste in advance for minimizing the harmful effects on the environment and humans [19]. The waste management process comprises the collection, transportation, and deployment of different bins for disposing of waste and transportation (Figure 3). Recycling is the process of turning waste material into usable material.

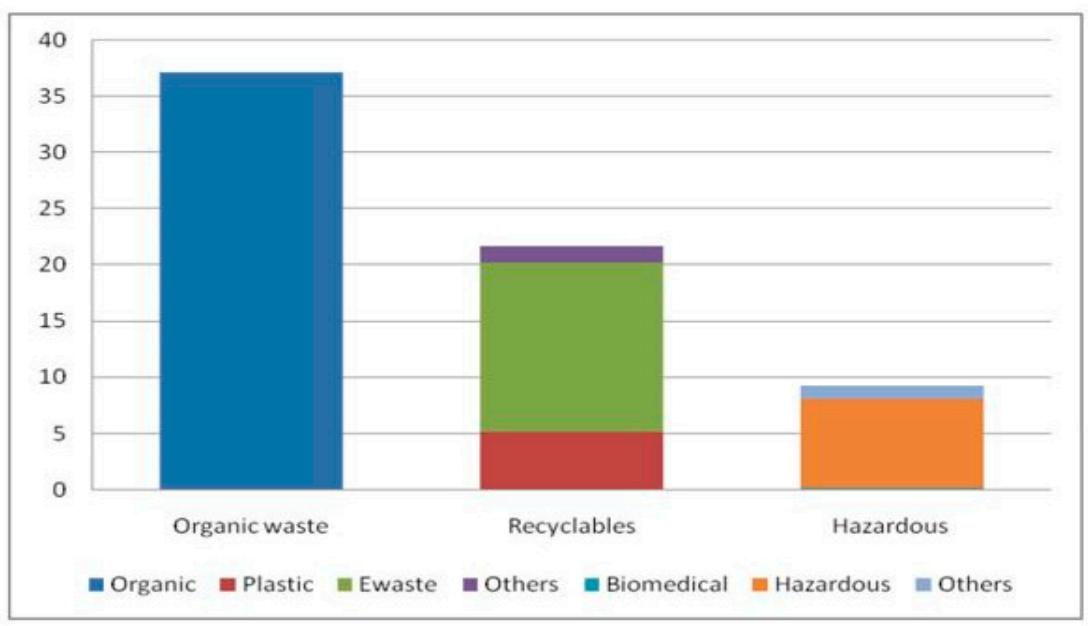

Figure 2. Waste composition in India (million metrics tonnes per annum), Source: PIB 2016 [7].

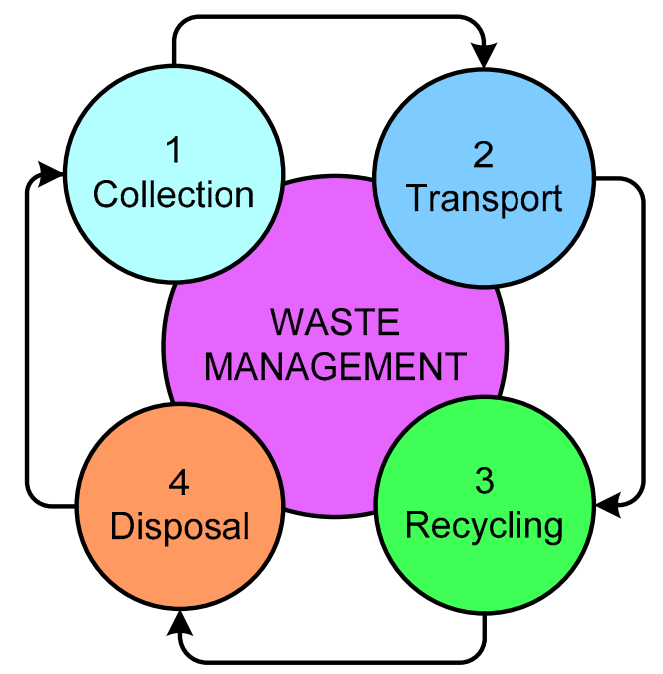

Figure 3. Stages in SWM.

In order to resolve the growing problems in SWM, information and communication technologies (ICTs) are becoming progressively valuable due to the increasing need for automatic data processing, identification, connectivity, storage, and analysis concerning rapid and parallel computation [20]. ICT is widely recognized as a technology that assists in data collection, processing, and communicating information [21]. ICT provides a convenient way for addressing the SWM issues due to its ability to enable access to information instantly from any remote location [22]. An evident incentive to use ICTs for achieving the broad SWM objectives will allow communities to achieve sustainable urban development. Even in the paradigm of smart city, the (ICT) plays a crucial role in the establishment, implementation, and empowerment of a sustainable growth environment [23]. ICTs are becoming more and more critical because of the increasing demands on acquisition, dissemination, and interpretation of large data along with fast computing capabilities for meeting the goals of automated and intelligent SWM systems. Innovations in MEMS technology 
have encouraged to build of advanced and technologically effective systems for SWM during these past few decades [24], and many studies have proven that ICTs are capable of tackling the distinct issues of SWM in terms of environment, operational cost, and time [25].

ICT technologies such as radiofrequency identification (RFID), geographic information system (GIS), and global positioning system (GPS) are used for monitoring solid waste collection trucks and containers. In the instance of containers, such technologies were employed to autonomously determine the container's level by integrating machine learning and image processing techniques. Genetic algorithms have been used to optimize solid waste collection routes to promote population well-being while reducing fuel use and pollution (noise and visual). Solutions are not limited to solving present issues but also to developing situations and products with an eye towards the future. Yet many investigations are considering only static data instead of real-time for routing optimization.

Table 1 provides the comparative analysis of the review studies based on SWM with the present study. The discussion of complete ICT technologies including IoT and blockchain is not mentioned in the previous studies. Few studies provide the discussion of ICT technologies up to geo-spatial technologies, wireless data acquisition, and wireless data communication technologies. Few studies specifically discussed only IoT in the SWM for smart solutions. However, this article provides a comprehensive discussion of a variety of ICT technologies, including IoT and SWM blockchain technologies. Moreover, this article provides the limitations of distinct IoT architecture for SWM in terms of wireless communication. This article also provides the concept of blockchain implementation in SWM with pictorial representation. Finally, this article provides recommendations for the enhancement of the SWM mechanism with an advanced approach. Architecture is also suggested to implement in SWM for implementing reliable and wireless scalable systems in the communities.

Table 1. Comparative analysis of review studies of SWM.

\begin{tabular}{cc}
\hline Study & Description \\
\hline & $\begin{array}{c}\text { A comprehensive and } \\
\text { thorough survey of } \\
\text { ICT-enabled waste } \\
\text { management models. }\end{array}$
\end{tabular}

A comprehensive

[27] evaluation of scholarly literature on decision support systems for SWM

ICTs and their usage in SWM systems to [28] unfold the issues and challenges

toward using an integrated technologies-based system.

A thorough analysis of the associated literature based

on IoT infrastructure for
effective waste [29] management in urban environments is conducted.

Application
Details on the strengths
and weaknesses of
several models to
expose their features.
The analysis and
discussion presented
intends to assist
researchers and
managers in gathering
ideas on
technologies/methods

\section{ICTs and their application}

in SWM to facilitate the search for planning and design of a sustainable new system.
An IoT-based reference model is presented, as well as a comparison study of the various options.

Advantage

It lays the foundation for the delivery of new models in the field

There were a few systems

that were directly applied to the management of materials reuse from building and demolition trash, waste output in the industry, and old industrial machinery.
It provides a brief idea of ICT integration in the SWM information regarding other ICT technologies such as IoT and blockchain

This study addresses the decision support system for the SWM. In addition, the information related to ICT technologies is not available in the study
The discussion and
importance of advanced technologies such as provided in this study

\section{The most relevant} techniques are highlighted, and open research questions on the topic are identified
This study provides a review of IoT only; it does not cover the other previous technologies implemented in SWM 
The major contributions of the study are as follows:

a A thorough analysis of the article based on ICT technologies is analysed.

b The significance, function, and limitation of each ICT technology for SWM are detailed presented.

c The importance of vision node, blockchain-based waste-to-money model, local network and gateway-based architecture is the recommendations that are concluded from the review.

The structure of the study is as follows. Figure 1 illustrates the structure of the paper. In the Section 2 covers the materials and methods of the review. Section 3 covers the technologies that have been implemented in SWM such as geo-spatial, wireless data acquisition, wireless data communication, IoT, and blockchain. Section 4 covers the results of the review. Section 5 covers possible research challenges and suggestions, and Section 6 covers the novelty of the study.

\section{Materials and Methods}

In this section, we present the materials and methods that are implemented for conducting the review on solid waste management. In this, the materials and methods are presented in the following pattern such as search strategy and selection criteria, followed by collection and extraction of data and then data analysis. This review is primarily focused on the progress of ICT technologies in solid waste management. The primary research question framed is: "Which ICT technologies are targeted in solid waste management?" Based on this research question, we have carried out gathering the research articles from different databases such as IEEE, Science Direct, Web of Science, and Scopus. To answer the research question, we explored the publications with logical strings.

- The following string is considered for the inclusion of publication ("solid waste management" or "solid waste", "bin level detection" or "waste management" or "garbage level detection" or "municipal solid waste management" or "waste collection" or "waste monitoring" or "trash bin level monitoring" or "bin level monitoring systems" or "smart bin" or "route optimization"). AND ("Information and Communication technology $\{\mathrm{ICT}\}$ " or "geo-spatial technologies" or geographic information system" or "GIS" or "geoprocessing" or "geographical information system" or "data acquisition" or "data communication" or "LoRaWAN").

- The following string is considered for the exclusion of publication ("wastewater treatment" or "electronic waste" or "medical waste" or "radioactive" or "construction and demolition waste" or "sludge management").

The above search strings are applied in available search filters of IEEE, Science Direct, Web of Science, and Scopus. In Science Direct, Web of Science, and Scopus, we have searched articles with title, abstract, and keywords fields. In the case of IEEE, we searched the articles with abstracts. This review considered publications from 2008 to 2021. The publications between 2008 and 2021 are excessive, and to filter the quality publication, we applied an approach. It was observed that the same studies were repeated with the same method in different years, so these publications were excluded for review.

In addition, conference papers of limited quality were considered, as most conference papers lacked a factual approach and proof of concept. After thorough filtration, the publication pattern that was considered for review is presented in Figure 4. The publication pattern is presented year-wise and journal and conference-wise. As discussed earlier, quality journals are considered over the conference papers by applying the logical strings. In the analysis, we classified the different types of ICT technologies (Figure 5) that are implemented in SWM such as geo-spatial technologies, wireless data acquisition, wireless data communication, and IoTs. In the classification, the greatest number of articles are represented with IoT (35\%) followed by geo-spatial (27\%), wireless data acquisition $(21 \%)$, and wireless data communication (17\%). These technologies provide the ability to set up a remote access environment in SWM. These ICT technologies have been in- 
corporated into SWM to monitor bins, locate bins, optimize routes, and monitor bins in real-time. In spatial technologies, most systems are implemented by integrating two or more technologies. Based on this classification, the remaining study is organized as shown in Figure 6. As per analysis of the different articles for the study, we have identified Critical Reviews in Environmental Science and Technology, Waste Management (Elsevier), Journal of Cleaner Production (Elsevier), Waste Management and Research: The Journal for a Sustainable Circular Economy (WMandR), and IEEE Access. The authors are Pinjing He, Umberto Arena, Dimitrios Komilis, and Professor Nicole Berge.

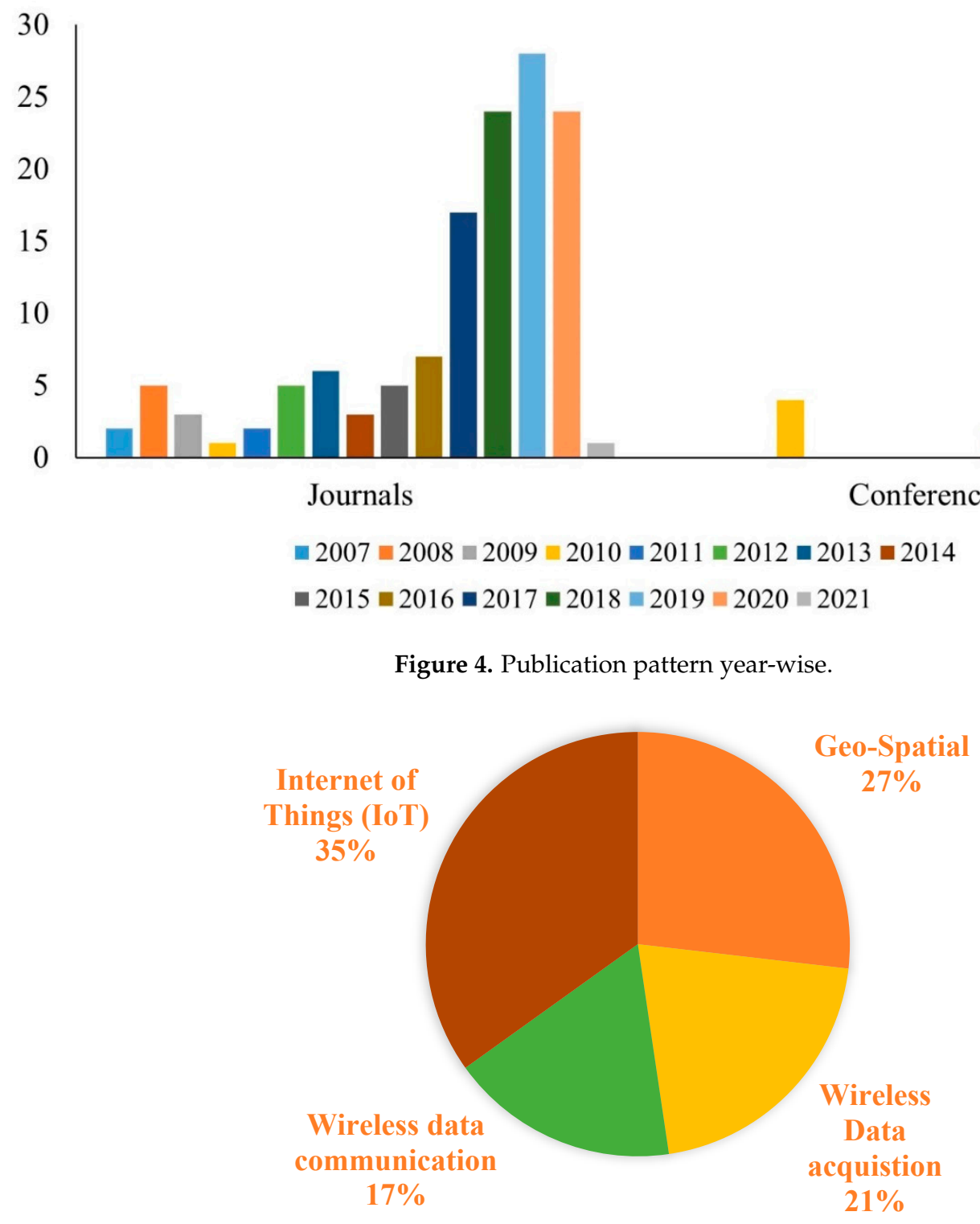

Figure 5. Distribution of papers based on technologies. 


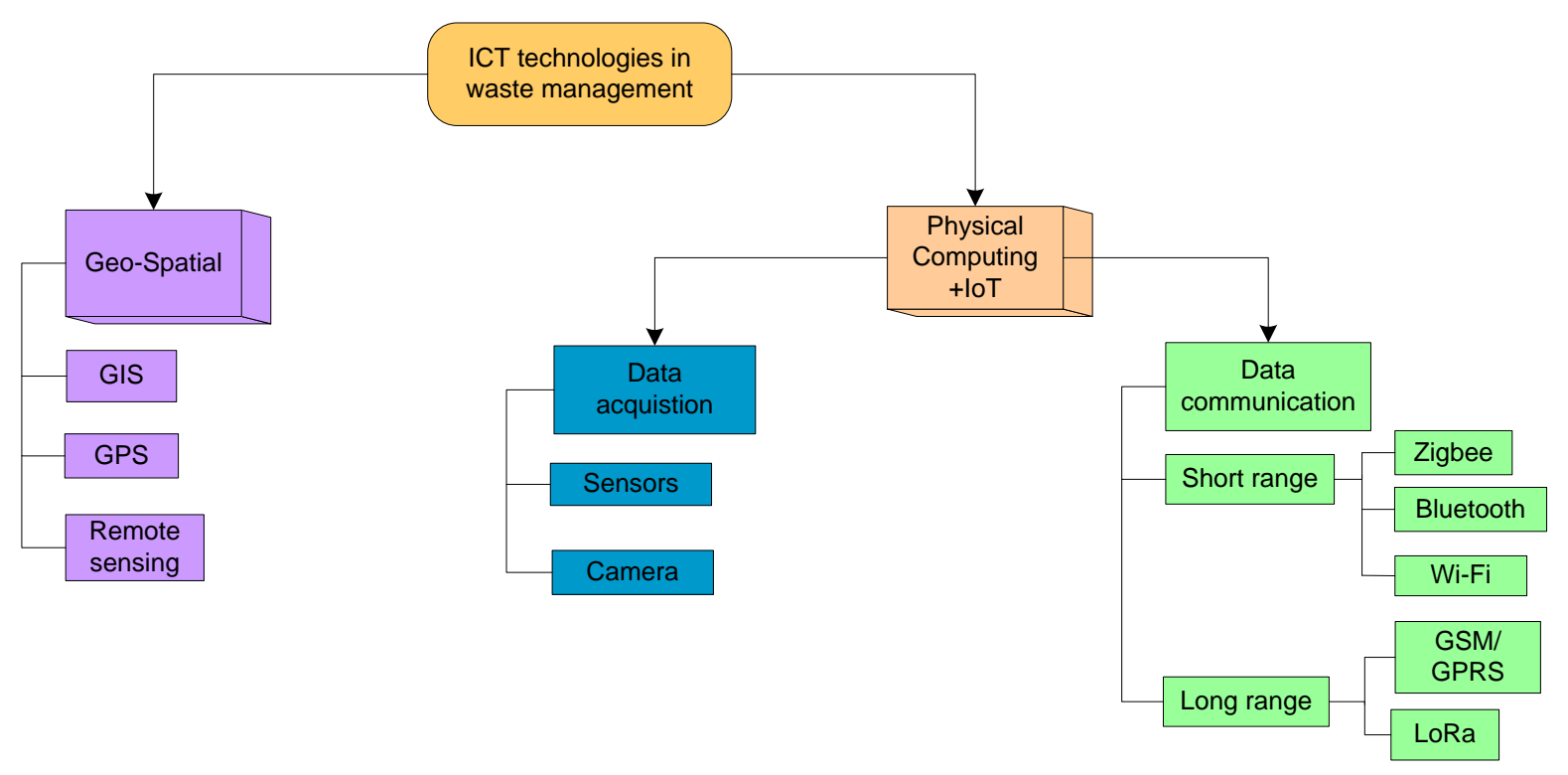

Figure 6. Technologies in solid waste management.

\section{Description of Previous Methodology}

In this section, we discuss the different previous methodologies that were carried out in the previous study. The significance and implementation of the methodology used in SWM are presented. From the analysis of the previous literature, we drew conclusions about the following ICT technologies such as geo-spatial, wireless data acquisition, wireless data communication, IoT, and blockchain technology:

- Geo-Spatial: From the analysis, it is concluded that geo-spatial technology is the initial ICT technology that is implemented in the SWM to monitor waste collection and generation. In this technology, we have evaluated the usage of geo-spatial technology for different applications of SWM with limitations.

- Wireless Data Acquisition: Due to rapid development in materials, the size of electronics materials is reduced in micro and nano size. This innovation led to the development of the data acquisition techniques such as sensors. Data acquisition technology uses sensors to acquire information by capturing quantities of chemical, biological, or physical properties and converting them into readable signals. We have evaluated the different types of data acquisition technologies that have been implemented in SWM with function.

- Wireless Data Communication: Wireless data communication has a significant role in any application to transmit data from one location to another location. In this study, we have evaluated different types of communication protocols that are implemented in SWM to communicate the sensor data. Here, we also evaluated the limitations and advantages of the different communication protocols in the SWM.

- IoT: IoT is widely implemented in distinct applications to enable real-time monitoring. In this study, we evaluated the implementation of IoT for different functions of SWM. In addition, to IoT studies, this review also evaluates IoT studies with cloud servers to check real-time implementation in SWM.

- Blockchain: Blockchain is the emerging approach that is implemented in the SWM to enhance digital documentation and circular economy. Here, we have evaluated the applications of blockchain in the SWM.

\section{Technologies Implemented for SWM}

In this section, we discuss distinct ICT technologies that have been identified through the analysis. Here, the individual ICT technologies are addressed in detailed with applications and limitations in tabular form. 


\subsection{Geo-Spatial}

GIS, GPS, and remote sensing (RS) are the geo-spatial technologies are employed for route optimization, optimal route, selecting dumping site, and waste generation information [30]. Geo-spatial technology is the technology that facilitates obtaining the data referenced to the earth. This technology will enable the establishment of intelligent decisions from the maps and models to acquire the desired result. Geo-spatial technology can track each event during trucks transportation concerning to changing in the surface of the earth. GIS, GPS, and RS are three geo-spatial technologies that are being implemented in the waste management system. Site selection [31-34], route optimization [35-38], bin location selection [39-42], and waste generation estimation [43] are accomplished by GIS. Vehicle tracking [44], route scheduling [45-47], driver tracking [48], and collection monitoring [49-51] are the activities that are possible with GPS. Environment assessment and environment feature monitoring are achieved with the assistance of RS [52].

Table 2 illustrates the previous studies that utilized the GIS in the SWM. The previous studies that are available in the table primarily focused on route optimization. For route optimization, the GIS is integrated with distinct models, namely agent-based and equationbased, 3D-based, decision support system (DSS), and dual-phase. The combination of GIS with the aforementioned models is implemented in SWM for achieving the efficient optimal path during the waste collection. Moreover, GIS is integrated with the fuzzy logic, RS for site selection, and placement of the bins. ArcGIS software is employed for allocation of bin and route optimization, and QGIS is useful for estimating the amount of waste generation at a particular site. The objective of GIS is to assist the municipal authorities with the proper implementation of the waste collection system and disposal unit.

Table 2. A detailed survey on GIS.

\begin{tabular}{|c|c|c|c|c|}
\hline Reference & Spatial Technology & Application & Function & Limitations of Study \\
\hline [32] & $\begin{array}{l}\text { GIS and remote } \\
\text { sensing (RS) }\end{array}$ & $\begin{array}{l}\text { Site selection and } \\
\text { bin location }\end{array}$ & $\begin{array}{l}\text { Siting the landfill and bin } \\
\text { location for waste disposal. }\end{array}$ & $\begin{array}{l}\text { Time-consuming and } \\
\text { requires high-end } \\
\text { infrastructure. }\end{array}$ \\
\hline [33] & $\begin{array}{l}\text { GIS and multiple } \\
\text { criteria decision } \\
\text { analysis (MCDA) }\end{array}$ & Landfill site selection & $\begin{array}{l}\text { Integrating the approach of } \\
\text { GIS and MCDA is effective } \\
\text { in landfill site selection. }\end{array}$ & $\begin{array}{c}\text { Soil type } \\
\text { Geo-techniques features } \\
\text { need to be considered for the } \\
\text { evaluating the risk } \\
\text { of environment. }\end{array}$ \\
\hline$[38]$ & GIS & Bin allocation & $\begin{array}{l}\text { Allocation of a bin for } \\
\text { minimizing the collection } \\
\text { costs and } \mathrm{CO}_{2} \text { emissions. }\end{array}$ & $\begin{array}{l}\text { Necessary to implement } \\
\text { routing for reducing the } \\
\text { transportation cost and } \\
\quad \mathrm{CO}_{2} \text { emissions. }\end{array}$ \\
\hline [39] & GIS & Route planning & $\begin{array}{l}\text { Selecting an optimal route } \\
\text { for waste collection. }\end{array}$ & $\begin{array}{l}\text { Require high-skilled person } \\
\text { for implementing } \\
\text { this system. }\end{array}$ \\
\hline$[40]$ & ArcGIS tool & $\begin{array}{l}\text { Allocation of bin and } \\
\text { route optimization }\end{array}$ & $\begin{array}{l}\text { ArcGIS tool is } \\
\text { implemented for efficient } \\
\text { waste collection. }\end{array}$ & $\begin{array}{l}\text { The study is limited to one } \\
\text { particular location. The same } \\
\text { model is unfeasible for } \\
\text { other locations. }\end{array}$ \\
\hline [49] & GIS + RFID + GSM & Monitoring of the bins & $\begin{array}{l}\text { Integration of three distinct } \\
\text { technologies for } \\
\text { monitoring the bins and } \\
\text { tracking the truck. }\end{array}$ & $\begin{array}{c}\text { The communication network } \\
\text { in this study consumes } \\
\text { high power. }\end{array}$ \\
\hline$[50]$ & $\begin{array}{l}\text { Integration of GIS, } \\
\text { agent-based, and } \\
\text { equation-based model }\end{array}$ & Route optimization & $\begin{array}{l}\text { Optimizing the route for } \\
\text { the waste collection. }\end{array}$ & $\begin{array}{l}\text { This study is focused on the } \\
\text { collection time, travel time, } \\
\text { and travel distance. }\end{array}$ \\
\hline
\end{tabular}


Table 2. Cont.

\begin{tabular}{|c|c|c|c|c|}
\hline Reference & Spatial Technology & Application & Function & Limitations of Study \\
\hline$[51]$ & $\begin{array}{c}\text { Integration of GIS and } \\
\text { fuzzy logic }\end{array}$ & Site selection & Selecting the landfill site. & $\begin{array}{l}\text { Requires high-processing } \\
\text { unit for the implementation. }\end{array}$ \\
\hline [52] & GIS & Bin location & $\begin{array}{l}\text { Selecting the location for } \\
\text { deployment of bins for } \\
\text { effective collection. }\end{array}$ & $\begin{array}{l}\text { Overflow of the waste from } \\
\text { the garbage bins is not } \\
\text { addressed, as it is } \\
\text { environmental risk. }\end{array}$ \\
\hline [53] & 3D-based GIS model. & Route optimization & $\begin{array}{l}\text { Reducing the fuel by } \\
\text { optimization in route. }\end{array}$ & $\begin{array}{l}\text { Reducing the fuel cost also } \\
\text { depends upon the type of the } \\
\text { vehicles and roads. }\end{array}$ \\
\hline$[54]$ & $\begin{array}{l}\text { GIS-based decision } \\
\text { support system (DSS) }\end{array}$ & $\begin{array}{l}\text { Routing and } \\
\text { scheduling }\end{array}$ & $\begin{array}{l}\text { Optimization and } \\
\text { scheduling of routes for } \\
\text { solid waste collection. }\end{array}$ & $\begin{array}{l}\text { It is difficult to schedule a } \\
\text { waste collection, as the } \\
\text { amount of waste disposed in } \\
\text { the bins is not estimated. }\end{array}$ \\
\hline [55] & $\begin{array}{l}\text { GIS-based spatial } \\
\text { analysis }\end{array}$ & $\begin{array}{l}\text { Groundwater risk } \\
\text { assessment }\end{array}$ & $\begin{array}{l}\text { Assessment of } \\
\text { groundwater } \\
\text { contamination. }\end{array}$ & $\begin{array}{l}\text { Limited for assessment of } \\
\text { ground water, and } \\
\text { monitoring of the other } \\
\text { parameters in landfill site } \\
\text { is lacking. }\end{array}$ \\
\hline [56] & GIS-based spatial & $\begin{array}{l}\text { Estimation of waste } \\
\text { generation }\end{array}$ & $\begin{array}{l}\text { Estimation of waste } \\
\text { generation in an urban } \\
\text { environment. }\end{array}$ & $\begin{array}{l}\text { Proposed model should be } \\
\text { tested in a larger area to } \\
\text { enhance the reliability of the } \\
\text { derived results. }\end{array}$ \\
\hline$[57,58]$ & GIS-based DSS & Route optimization & $\begin{array}{c}\text { Dynamic route } \\
\text { optimization for collection. }\end{array}$ & $\begin{array}{c}\text { The focus of this work is } \\
\text { limited to recycling } \\
\text { management. }\end{array}$ \\
\hline [59] & Dual-phase GIS model & Route optimization & $\begin{array}{l}\text { Enhancing the waste } \\
\text { collection route. }\end{array}$ & $\begin{array}{l}\text { Ineffective in } \\
\text { recognizing the situation } \\
\text { with the lowest system cost. }\end{array}$ \\
\hline$[60]$ & GIS & $\begin{array}{l}\text { Quantifying the waste } \\
\text { pickers }\end{array}$ & $\begin{array}{l}\text { Evaluating informal and } \\
\text { formal waste pickers. }\end{array}$ & $\begin{array}{l}\text { Long-term MSWM plans } \\
\text { should be presented } \\
\text { for valorising the circular } \\
\text { economy activities. }\end{array}$ \\
\hline$[61]$ & GIS and remote sensing & Site selection & $\begin{array}{l}\text { Selecting the appropriate } \\
\text { location for waste disposal. }\end{array}$ & $\begin{array}{c}\text { During the practical } \\
\text { implementation, the system } \\
\text { constraints arise. }\end{array}$ \\
\hline$[62]$ & Quantum GIS (QGIS) & $\begin{array}{l}\text { Waste generation } \\
\text { information }\end{array}$ & $\begin{array}{l}\text { Predictive analysis and } \\
\text { QGIS are used } \\
\text { for evaluating } \\
\text { waste generation. }\end{array}$ & $\begin{array}{c}\text { Creating an optimal route for } \\
\text { the garbage truck with } \\
\text { descriptive and } \\
\text { predictive analysis. }\end{array}$ \\
\hline [63] & GIS & $\begin{array}{l}\text { Selection of } \\
\text { disposal site }\end{array}$ & $\begin{array}{l}\text { Analysis of the GIS data for } \\
\text { selecting the disposal site }\end{array}$ & $\begin{array}{l}\text { Manual analysis must also be } \\
\text { integrated with GIS for } \\
\text { effective selection of } \\
\text { disposal site. }\end{array}$ \\
\hline$[64]$ & GIS & Route optimization & $\begin{array}{l}\text { Implementing GIS for } \\
\text { finding the optimal route } \\
\text { for waste collection. }\end{array}$ & $\begin{array}{l}\text { The participation of } \\
\text { municipal decision makers in } \\
\text { approving multi-criteria } \\
\text { decision aids } \\
\text { approach effectively. }\end{array}$ \\
\hline
\end{tabular}

GPS assists in tracking the objects based on longitude and latitude. In MSW, GPS combines with GIS and RFID for tracking the trucks and drivers during the waste collection, and it also helps in optimization of the routes. Moreover, GPS and GIS support landfill 
selection and assessment of waste management. Table 3 provides the detail function of the GPS in MSW.

Table 3. A detailed survey on GPS.

\begin{tabular}{|c|c|c|c|c|}
\hline Research & Spatial Technology & Application & Function & Limitations of the Study \\
\hline [65] & GPS and GIS & Route optimization & $\begin{array}{l}\text { Integration of GIS and GPS } \\
\text { for optimizing routes for } \\
\text { waste collection. }\end{array}$ & $\begin{array}{l}\text { Real-time data of the route } \\
\text { optimization is lacking. }\end{array}$ \\
\hline$[66]$ & GPS & Vehicle tracking & $\begin{array}{l}\text { Analysing the delay of } \\
\text { vehicles at the } \\
\text { transfer station. }\end{array}$ & $\begin{array}{l}\text { Limiting the analysis to } 1 \\
\text { year of data may have } \\
\text { concealed a few seasonal } \\
\text { dissimilarities in the data. }\end{array}$ \\
\hline [67] & GPS & Drive tracking & $\begin{array}{l}\text { Communicates the precise } \\
\text { activities of drivers. }\end{array}$ & $\begin{array}{l}\text { Real-time communication } \\
\text { system is not addressed. }\end{array}$ \\
\hline [68] & GPS and GIS & $\begin{array}{l}\text { Optimization of } \\
\text { collection }\end{array}$ & $\begin{array}{l}\text { Spatial data and real-time } \\
\text { data for tracking and } \\
\text { optimizing the collection. }\end{array}$ & $\begin{array}{c}\text { Sensor fusion techniques are } \\
\text { not utilized for classification } \\
\text { of waste. }\end{array}$ \\
\hline [69] & GPS and RFID & Route optimization & $\begin{array}{l}\text { Automated billing and route } \\
\text { optimization. }\end{array}$ & $\begin{array}{c}\text { RFID technology is only able } \\
\text { to communicate information } \\
\text { to the limited range. }\end{array}$ \\
\hline [70] & GIS & Site selection & $\begin{array}{l}\text { Identifying the solid waste } \\
\text { dumping site for reducing } \\
\text { the environmental risk and } \\
\text { human health. }\end{array}$ & $\begin{array}{l}\text { Lacking the consideration of } \\
\text { recycling and reuse approach } \\
\text { for reducing the } \\
\text { environmental risk. }\end{array}$ \\
\hline [71] & GPS and GIS & $\begin{array}{c}\text { Assessment of waste } \\
\text { management }\end{array}$ & $\begin{array}{l}\text { Integrating for assessing the } \\
\text { waste management system. }\end{array}$ & $\begin{array}{l}\text { Assessment is limited to } \\
\text { theoretical approach. }\end{array}$ \\
\hline [72] & GPS and GIS & Land fill selection & $\begin{array}{l}\text { Integrating GIS and GPS for } \\
\text { selecting a feasible location } \\
\text { for the disposal. }\end{array}$ & $\begin{array}{l}\text { Tracking system is needed to } \\
\text { be implemented for making } \\
\text { the system effectively. }\end{array}$ \\
\hline
\end{tabular}

RS is utilized for monitoring and analysing the physical attributes of an area. In SWM, the RS is employed for the environmental assessment of the water bodies. Moreover, RS is utilized for landfill sites regarding water bodies polluting due to the decomposition of mixed waste in the land. RS is also integrated to estimate the waste generation and identify the appropriate site for constructing landfills for waste disposal. Table 4 provides the detailed function of the RS in SWM.

Table 4. A detailed survey on RS.

\begin{tabular}{|c|c|c|c|c|}
\hline Research & Spatial Technology & Application & Function & Limitations of the Study \\
\hline [73] & RS and GIS & $\begin{array}{l}\text { Environment } \\
\text { assessment }\end{array}$ & $\begin{array}{l}\text { Allotting landfill site that is far } \\
\text { away from water bodies. }\end{array}$ & $\begin{array}{l}\text { Implementation of RS and } \\
\text { GIS increases the } \\
\text { infrastructure cost. }\end{array}$ \\
\hline [74] & RS and GIS & $\begin{array}{l}\text { Site selection and } \\
\text { routing }\end{array}$ & $\begin{array}{l}\text { Selecting a waste disposal site } \\
\text { and providing the } \\
\text { optimal route. }\end{array}$ & $\begin{array}{l}\text { In optimal routing, the } \\
\text { profile of roads has } \\
\text { not considered. }\end{array}$ \\
\hline [75] & RS and GIS & $\begin{array}{l}\text { Environment } \\
\text { assessment }\end{array}$ & $\begin{array}{l}\text { Evaluating the feasible site for } \\
\text { disposal of waste far away } \\
\text { from the river bodies. }\end{array}$ & $\begin{array}{l}\text { Time consuming and high } \\
\text { cost for the real-time } \\
\text { implementation. }\end{array}$ \\
\hline [76] & RS and GIS & Waste generation & $\begin{array}{l}\text { Analysing the } \\
\text { waste generation. }\end{array}$ & $\begin{array}{l}\text { Simple Thiessen polygons to } \\
\text { evaluate the impact of } \\
\text { activities on specific area } \\
\text { with single } \\
\text { remote-sensing imagery. }\end{array}$ \\
\hline
\end{tabular}


Table 4. Cont

\begin{tabular}{ccccc}
\hline Research & Spatial Technology & Application & Function & Limitations of the Study \\
\hline$[77]$ & RS & Landfill site & $\begin{array}{c}\text { Detecting unauthorized } \\
\text { landfill sites. }\end{array}$ & Detection time is maximum. \\
\hline$[78]$ & RS and GIS & Landfill site & $\begin{array}{c}\text { Thiessen polygons for } \\
\text { obtaining the area of } \\
\text { influence around polygons } \\
\text { and the usage of a single } \\
\text { RS image. }\end{array}$ & $\begin{array}{c}\text { Ranking the landfill site. } \\
\text { ime operational } \\
\text { cost increases. }\end{array}$ \\
\hline
\end{tabular}

\subsection{Wireless Data Acquisition}

Wireless data acquisition technology is an eminent technology that acquires the realtime information of physical things without human intervention. The availability of real-time information encourages municipal authorities to track and monitor bins continuously [80]. Real-time information also assists in evaluating the generation pattern and quantity of waste in the containers, which indeed facilitate the trucks for collecting the waste at appropriate times to avoid overflow [81,82]. In the context of SWM, the following are wireless data acquisition technologies: (i) sensors and (ii) imaging technology. Sensors acquire the chemical, physical, and biological properties of any material and convert them into an electrical signal. Minimum computing power, low power consumption, and energy constraint are the benefits of the sensors. In many studies, researchers have addressed the significance of the sensor in SWM for the application of real-time quantity and weight of waste and emission of the gas from the garbage. Table 5 illustrates the detailed study of sensors and imaging technology implementation in SWM. From the table, it is identified that the following sensors, namely, weight sensor, temperature sensor, capacity sensor, gas sensor, and pressure sensor, are incorporated in SWM for sensing the status of the bins. In [83], an intelligent solid waste bin is proposed, where the bin's mechanisms are automated with the assistance of three distinct sensing technologies, namely, lid status sensing, waste level sensing, and weight sensing.

Imaging technology is another data acquisition technology that is widely implemented in the SWM for capturing and monitoring the visuals of the bins and surrounding environment. Camera and video surveillance $[84,85]$ are the imaging technologies that capture the digital images for prediction of the possible events related to the waste. Bin level detection [86,87], waste sorting [88-92], and collection monitoring are the applications of imaging technology for the SWM. The visuals, which are captured by camera, are beneficial for analysing the waste generation pattern and other activities with the assistance of AI techniques. Multi-layer Deep Learning System (MDLS) model is applied on the images for classifying the waste in bin by using AlexNet Convolutional Neural Network (CNN) algorithm [93]. 
Table 5. A detailed survey of wireless data acquisition technologies (sensors and imaging).

\begin{tabular}{|c|c|c|c|c|}
\hline Ref & Acquisition Technology & Application & Function & Limitations of the Study \\
\hline$[84]$ & Optical sensor & Waste sorting & $\begin{array}{l}\text { Sorting the mixed waste of } \\
\text { the bin. }\end{array}$ & $\begin{array}{l}\text { Communicating the data of } \\
\text { waste sorting is unavailable. }\end{array}$ \\
\hline$[85]$ & Camera & Waste collection & $\begin{array}{l}\text { Monitoring the } \\
\text { waste collection. }\end{array}$ & $\begin{array}{c}\text { Data processing consumes } \\
\text { high power due to } \\
\text { GSM module. }\end{array}$ \\
\hline [94] & Infrared sensor & Waste collection & $\begin{array}{l}\text { Enhancing the waste } \\
\text { collection event. }\end{array}$ & $\begin{array}{l}\text { Raspberry pi board enabled } \\
\text { with infrared sensor can only } \\
\text { communicate to the } \\
\text { short range. }\end{array}$ \\
\hline$[95]$ & $\begin{array}{l}\text { Ultrasonic sensor, } \\
\text { force-resistive sensor }\end{array}$ & Detection of bin level. & $\begin{array}{l}\text { Sensing the level of waste } \\
\text { in the bin. }\end{array}$ & $\begin{array}{l}\text { GSM module in the system } \\
\text { consumes high power. }\end{array}$ \\
\hline$[96]$ & Ultrasonic sensor & Detection of bin level & $\begin{array}{l}\text { Sensing the level of waste } \\
\text { in the bin. }\end{array}$ & $\begin{array}{l}\text { ESP8266 Wi-Fi Module in } \\
\text { the system communicates } \\
\text { only to the short range. }\end{array}$ \\
\hline [97] & Ultrasonic sensor & Waste collection & $\begin{array}{l}\text { Collecting waste } \\
\text { concerning the threshold } \\
\text { level of the bin. }\end{array}$ & $\begin{array}{l}\text { Internet connectivity should } \\
\text { be stable for sending the } \\
\text { threshold level of the bins. }\end{array}$ \\
\hline$[98]$ & Ultrasonic sensor & Waste collection & $\begin{array}{l}\text { Customized ultrasonic } \\
\text { sensor for waste collection. }\end{array}$ & $\begin{array}{l}\text { The system is lacking the } \\
\text { gateway for transmitting the } \\
\text { data to the server. }\end{array}$ \\
\hline [99] & Ultrasonic sensor & Waste collection & $\begin{array}{l}\text { Enabled threshold limit to } \\
\text { the bin for overcoming the } \\
\text { overflow of waste from } \\
\text { the bins. }\end{array}$ & $\begin{array}{l}\text { GSM module in the system } \\
\text { consumes maximum power. }\end{array}$ \\
\hline [100] & Infrared sensor & Bin level & $\begin{array}{l}\text { Sensing the level of waste } \\
\text { in the bin. }\end{array}$ & $\begin{array}{l}\text { Infrared sensor-based } \\
\text { system faces challenges due } \\
\text { to environmental issues. }\end{array}$ \\
\hline$[101]$ & Infrared sensor & Waste collection & $\begin{array}{l}\text { Monitoring the level } \\
\text { of waste. }\end{array}$ & $\begin{array}{l}\text { Detection of waste thrown } \\
\text { outside is a bit challenging } \\
\text { with infrared sensor. }\end{array}$ \\
\hline [102] & Camera & Waste collection & $\begin{array}{l}\text { Improving the efficiency of } \\
\text { the collection system. }\end{array}$ & $\begin{array}{l}\text { Communicating the visuals } \\
\text { data through GSM increases } \\
\text { the operational cost. }\end{array}$ \\
\hline [103] & Camera & $\begin{array}{l}\text { Outdoor condition of } \\
\text { bin }\end{array}$ & $\begin{array}{l}\text { Monitoring the outdoor } \\
\text { condition of the bins. }\end{array}$ & $\begin{array}{l}\text { Communication system is } \\
\text { missing for transmitting the } \\
\text { visuals data. }\end{array}$ \\
\hline$[104]$ & Camera & Bin identification & $\begin{array}{l}\text { Identifying the bins during } \\
\text { classification. }\end{array}$ & $\mathrm{N} / \mathrm{A}$ \\
\hline [105] & Camera & $\begin{array}{l}\text { Classification } \\
\text { of waste }\end{array}$ & $\begin{array}{c}\text { A deep learning } \\
\text { framework is implemented } \\
\text { on the image that was } \\
\text { acquired through } \\
\text { the camera. }\end{array}$ & $\begin{array}{l}\text { Wireless connectivity } \\
\text { is unavailable. }\end{array}$ \\
\hline$[106]$ & Camera & Bin sorting & $\begin{array}{l}\text { Mounted camera in the } \\
\text { robot for sorting the waste } \\
\text { in the bin. }\end{array}$ & $\begin{array}{l}\text { Implementing the robot with } \\
\text { camera raises the } \\
\text { infrastructure cost for } \\
\text { sorting the waste. }\end{array}$ \\
\hline [107] & Camera & Monitoring dumping & $\begin{array}{l}\text { Real-time monitoring } \\
\text { activities in the } \\
\text { dumping yard. }\end{array}$ & $\begin{array}{c}\text { An alert system is lacking for } \\
\text { sending the details of the } \\
\text { dumping activities. }\end{array}$ \\
\hline [108] & Ultrasonic sensor & Level of the waste & $\begin{array}{l}\text { Monitor the level of the } \\
\text { waste in the bin and } \\
\text { communicate to wireless } \\
\text { access point. }\end{array}$ & $\begin{array}{l}\text { Need to upgrade } \\
\text { communication protocol for } \\
\text { transmitting the data across } \\
\text { a long range. }\end{array}$ \\
\hline
\end{tabular}




\subsection{Wireless Data Communication}

Wireless data communication technologies in the SWM encourage transmitting the acquisition data and geo-spatial data to obtain a stable and reliable interconnection with the bins. The advent of communication technologies opens opportunities for communicating information from a remote location [109]. The wireless communication technologies are classified based on transmission range: (i) long-range communication and (ii) short-range communication. GSM/GPRS LoRa is the distinct long-range communication technologies that have been implementing in SWM. Zigbee Bluetooth and Wi-Fi [110] are short-range wireless communication in SWM. GSM/GPRS is long-range communication that operates on $900-1800 \mathrm{MHz}$ [111]. This communication can transmit the sensor information of the bins to the municipal authority across a long range. The major drawback of the GSM/GPRS in the SWM is the high-power consumption that generally occurs at the sensor node. However, the limitations of high power in the SWM are overridden by the long-range (LoRa). LoRa communication is low-power and long-range communication technology that can transmit the sensory information up to $5 \mathrm{~km}$ (urban) and $10 \mathrm{~km}$ (rural). The short-range wireless communication technologies including Zigbee consume low power for communicating the information. Bluetooth is another WPAN communication protocol that communicates the information with low power consumption. Wi-Fi (Wireless Fidelity) is a wireless local area network (WLAN) that can communicate information over Internet Protocol (IP). However, the short-range limitation of Bluetooth, ZigBee, and Wi-Fi is combatting the wide implementation in the SWM. Table 6 provides the detailed review of wireless communication technologies in SWM.

From the previous studies, it is concluded among five technologies that LoRa (Long Range) is the promising and reliable communication technology that meets the requirements in the SWM. Generally, the end devices are powered with battery. The embedding of GSM/GPRS and Wi-Fi consume high power for the data transmission. Zigbee and Bluetooth consume low power; however, these two technologies only transmit to the range of $100 \mathrm{~m}$. Thus, LoRa (Long Range) is the optimal technology that dissipates low energy with the long-range transmission reliably and securely. 
Table 6. A detailed review of wireless data communication technologies in SWM.

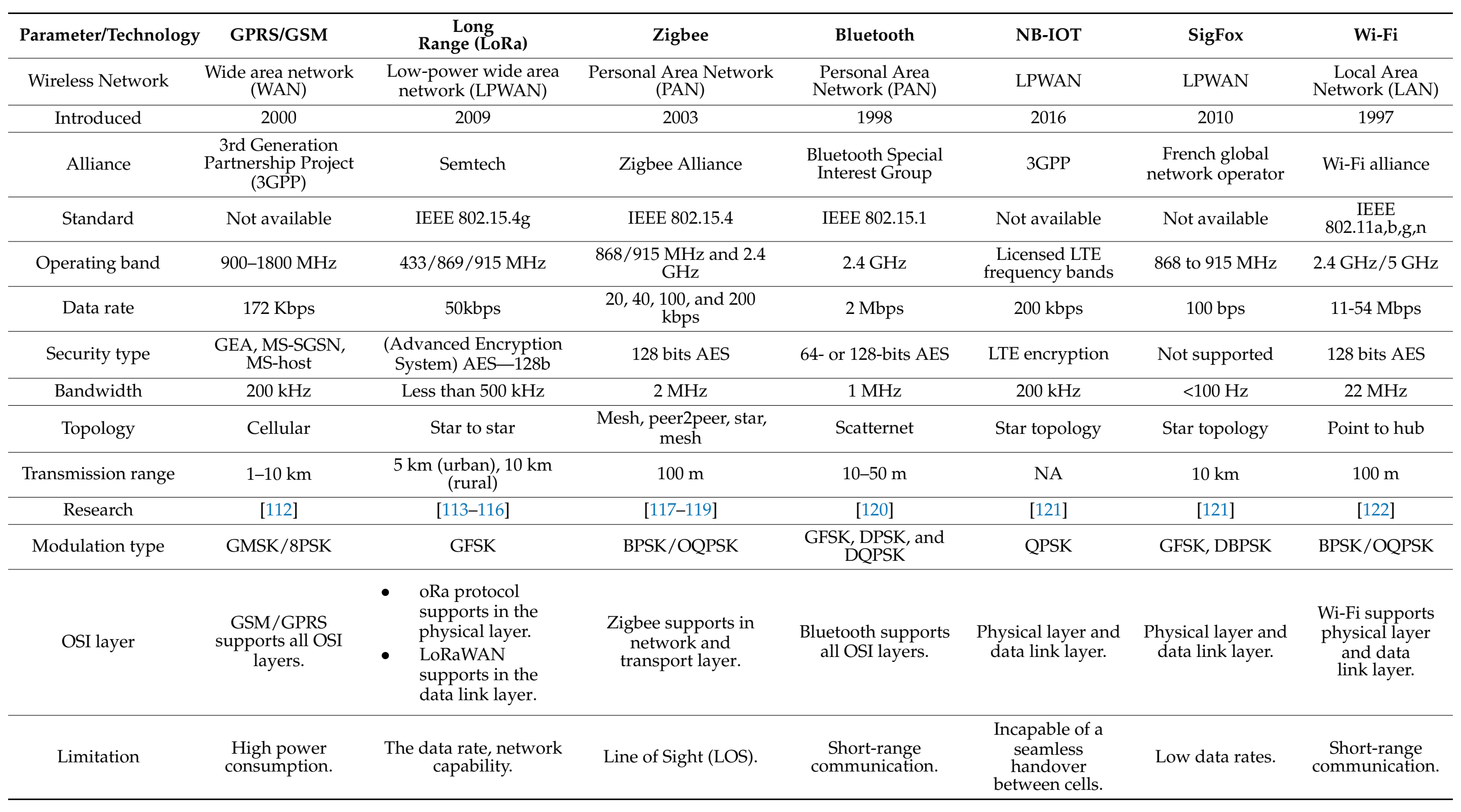




\subsection{IoT for SWM}

IoT is recognized as a platform that involves smart objects embedded with networking, sensors, and processing technologies that merge and operate simultaneously to provide an ecosystem in which intelligent services are delivered to end-users [123,124]. Internet of Things is a network of physical objects that are digitally connected to sense, monitor, and interact within a company and between the company. Supply chain enables agility, visibility, tracking, and information sharing to facilitate timely planning, control, and coordination of the supply chain processes [125].

Every technology has its architecture; the IoT consists of the three-layer architecture of IoT [126] and is shown in Figure 7. The perception layer, network layer, and application layer are part of the IoT architecture. The perception layer consists of sensors; the sensor senses changes in the physical things and the surrounding environment. In IoT, sensor technology plays a crucial part in monitoring physical objects/things. The network layer enables the transmission and processing of the sensor data using networks and servers. The application layer provides application-related services to the end-user and defines different applications in which the IoT can be deployed. In the context of SWM, IoT will enable the connecting of the bins to the internet for real-time monitoring and visualizing the status of the bins from any remote location. The implementation of IoT in SWM is illustrated in Table 7. Different parameters have been considered for evaluating the significance of IoT in waste management. Among all the research studies in the IoT for SWM, the primary focus is on monitoring the bins' fullness level. Generally, for measuring the level of the waste, an ultrasonic sensor is embedded in every study.

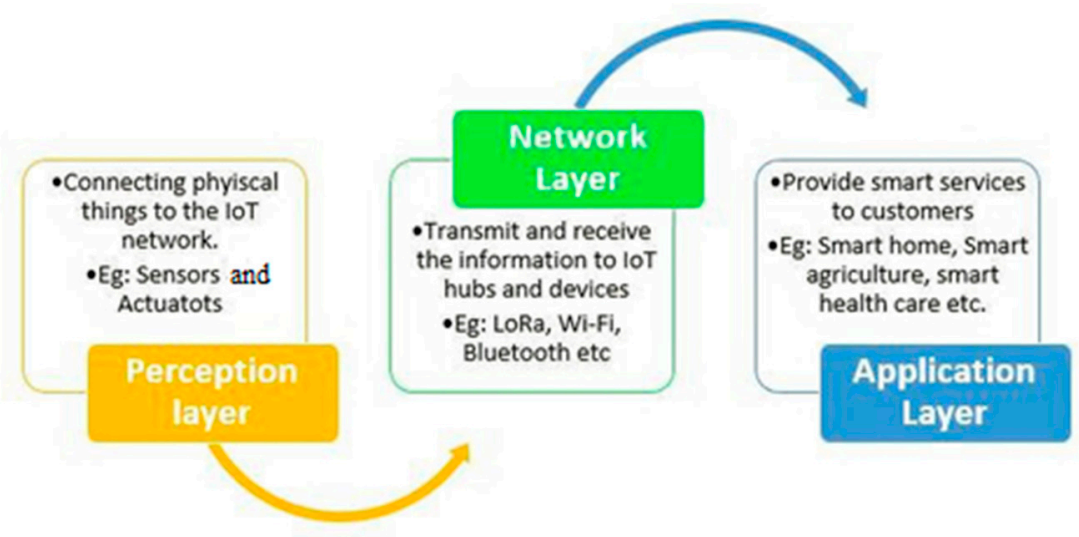

Figure 7. Basic Architecture of IoT.

In a few studies, the proximity sensor is embedded for sensing the nearby object and enabling the lid to open for disposal of the waste; a force-resistive sensor and load cell sensor are embedded for measuring the weight of the waste in the bin. Fire sensor is for sensing fire or smoke in the bin [127]. The gas sensor is for sensing the possible evolution of pungent gas from the waste, odour sensor for sensing the smell from the waste in the bin, and the moisture sensor for sensing the wetness on the waste. With the evolution of cloud computing technology, the bins are monitored through cloud. Cloud is one of the promising computing technologies where the data is analysed, computed, and stored. The different cloud platforms implemented in previous studies of SWM, namely, Ubidots, Amazon Web server (AWS) [128], Thingspeak server [129], Google Cloud server (GCP) [130], and local server, are considered in a few studies storing the sensor data of the bins. 
Table 7. IoT implementation in SWM.

\begin{tabular}{|c|c|c|c|c|c|c|}
\hline Study & Objective & Waste & Infrastructure & Sensing & Actuators & Software \\
\hline [131] & $\begin{array}{l}\text { Monitoring } \\
\text { the level }\end{array}$ & $\begin{array}{l}\text { Organic and } \\
\text { recycle waste }\end{array}$ & $\begin{array}{c}1 \text { bin in indoor and } \\
3 \text { bins in outdoor } \\
\text { environment }\end{array}$ & $\begin{array}{l}\text { Ultrasonic } \\
\text { sensor }\end{array}$ & Not specified & Cloud server \\
\hline [132] & Reduce food waste & Food & $\begin{array}{l}\text { Three smart } \\
\text { garbage bins with } \\
\text { RFID reader }\end{array}$ & Load cell & Motor & Mobile API \\
\hline [133] & $\begin{array}{l}\text { Waste discharging } \\
\text { and collection }\end{array}$ & All & $\begin{array}{l}\text { Customized bin for } \\
\text { sensing all types } \\
\text { of waste. }\end{array}$ & $\begin{array}{c}\text { Ultrasonic, } \\
\text { proximity, and } \\
\text { fire }\end{array}$ & Motor & $\begin{array}{l}\text { Amazon Web } \\
\text { server (AWS) }\end{array}$ \\
\hline [134] & Monitoring level & Solid waste & No & $\begin{array}{l}\text { Ultraviolet } \\
\text { (UV) }\end{array}$ & Not specified & Web portal \\
\hline [135] & $\begin{array}{c}\text { Waste collection } \\
\text { and monitoring } \\
\text { level }\end{array}$ & $\begin{array}{l}\text { Household } \\
\text { waste }\end{array}$ & Smart bin & $\begin{array}{l}\text { Ultrasonic } \\
\text { sensor }\end{array}$ & Not specified & Cloud server \\
\hline [136] & Monitoring level & Solid waste & Smart bin (2) & $\begin{array}{l}\text { Ultrasonic } \\
\text { sensor }\end{array}$ & Not specified & Mobile API \\
\hline [137] & $\begin{array}{l}\text { Monitoring the } \\
\text { level and alerting }\end{array}$ & Solid waste & Three garbage bins & $\begin{array}{l}\text { Ultrasonic } \\
\text { sensor }\end{array}$ & Not specified & $\begin{array}{l}\text { Ubidots IoT } \\
\text { cloud }\end{array}$ \\
\hline [138] & Monitoring level & Solid waste & No & $\begin{array}{c}\text { Ultrasonic } \\
\text { sensor }\end{array}$ & Not specified & $\begin{array}{c}\text { Thingspeak } \\
\text { server }\end{array}$ \\
\hline [139] & $\begin{array}{l}\text { Monitoring level } \\
\text { and moisture }\end{array}$ & Solid waste & $\begin{array}{l}\text { Dry bin and } \\
\text { wet bin }\end{array}$ & $\begin{array}{c}\text { Ultrasonic } \\
\text { sensor, } \\
\text { moisture sensor }\end{array}$ & Motor & Local server \\
\hline [140] & $\begin{array}{l}\text { Monitoring level } \\
\text { and weight }\end{array}$ & Solid waste & No & $\begin{array}{l}\text { Ultrasonic } \\
\text { sensor, weight } \\
\text { sensor, and } \\
\text { odour sensor }\end{array}$ & Not specified & $\begin{array}{c}\text { Google Cloud } \\
\text { server }(\mathrm{GCP})\end{array}$ \\
\hline [141] & $\begin{array}{l}\text { Monitoring filling } \\
\text { level and } \\
\text { provide location }\end{array}$ & Solid waste & $\begin{array}{c}8 \text { bins are } \\
\text { implemented with } \\
\text { sensor nodes }\end{array}$ & $\begin{array}{l}\text { Ultrasonic } \\
\text { sensor }\end{array}$ & Not available & Cloud server \\
\hline
\end{tabular}

From the previous studies, we have evaluated the IoT architecture of SWM and have concluded that the typical architecture illustrated in the Figure 8 is widely proposed. In this architecture, " $n$ " number of the bins in the perception layer have communication capability, where they transmit the filling level of the waste. The sensor node is deployed in the bins for enabling the communication to the cloud server with GSM/Node MCU modem.

In IoT, the controller and wireless communication selection plays a significant role because the sensor node are energy-constrained devices and are deployed in the outdoor environment where the electrical power grid availability is less. Therefore, in we discuss the studies that integrated distinct controllers and communication Table 8 for achieving the goal of IoT for SWM. Raspberry pi 3, Atmega 328P, R5F100LEA, Arduino Uno and WEMOS are the controllers that have embedded sensor nodes for monitoring the bins' status. 


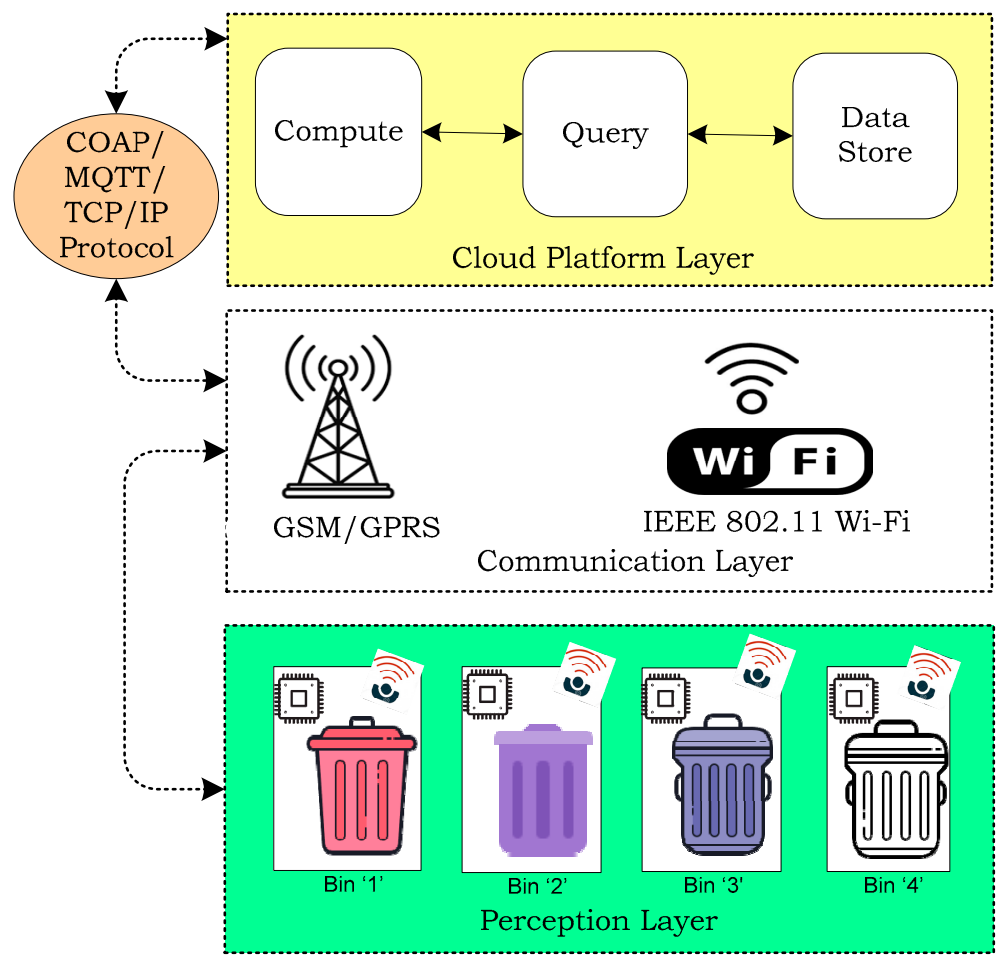

Figure 8. IoT based architecture of the waste management system.

Table 8. Technical specifications of previous studies of IoT-based SWM.

\begin{tabular}{|c|c|c|c|c|c|c|c|}
\hline Study & $\begin{array}{l}\text { Controller } \\
\text { Unit }\end{array}$ & $\begin{array}{l}\text { Bus Width } \\
\text { (Bits) }\end{array}$ & $\begin{array}{l}\text { Operating } \\
\text { Frequency } \\
\text { (MHz/GHz) }\end{array}$ & $\begin{array}{c}\text { Operating } \\
\text { Voltage (V) }\end{array}$ & $\begin{array}{c}\text { Wireless } \\
\text { Communication }\end{array}$ & Wi-Fi & $\begin{array}{c}\text { Customized } \\
\text { Prototype }\end{array}$ \\
\hline [97] & R5F100LEA & 16 & $32 \mathrm{MHz}$ & 5.5 & $\begin{array}{l}\text { Global system for } \\
\text { mobile } \\
\text { communication } \\
\text { (GSM) }\end{array}$ & Not available & No \\
\hline [114] & Atmega 328P & 8 & $16 \mathrm{MHz}$ & 3.3 & NA & $\begin{array}{l}\text { RKI-1451 } \\
\text { (ESP 8266) }\end{array}$ & No \\
\hline [131] & $\begin{array}{c}\text { Not } \\
\text { discussed }\end{array}$ & - & - & - & $\begin{array}{c}\text { CDMA2000 } \\
\text { EV-DO, RFID }\end{array}$ & Not available & Yes \\
\hline [132] & Arduino Uno & 8 & $8 \mathrm{MHz}$ & $7-12$ & $\begin{array}{l}\text { Global system for } \\
\text { mobile } \\
\text { communication } \\
\text { (GSM) }\end{array}$ & - & No \\
\hline [134] & Raspberry pi & 64 & $1.2 \mathrm{GHz}$ & $5,3,3$ & Zigbee & Inbuilt & No \\
\hline [135] & WEMOS & - & $80 \mathrm{MHz} / 160 \mathrm{MHz}$ & 3.3 & - & $\begin{array}{c}\text { Inbuilt (ESP } \\
8266)\end{array}$ & No \\
\hline$[136]$ & Arduino Uno & 8 & $8 \mathrm{MHz}$ & $7-12$ & NA & - & No \\
\hline $\begin{array}{l}{[137,} \\
138]\end{array}$ & Arduino Uno & 8 & $8 \mathrm{MHz}$ & $7-12$ & NA & $\begin{array}{l}\text { ESP } 8266 \\
\text { module }\end{array}$ & No \\
\hline [139] & $\begin{array}{l}\text { Single chip } \\
\text { controller }\end{array}$ & $\begin{array}{c}\text { Not } \\
\text { mentioned }\end{array}$ & Not mentioned & $\begin{array}{c}\text { Not } \\
\text { mentioned }\end{array}$ & NA & Node MCU & Yes \\
\hline
\end{tabular}

Wireless communication technologies such as GSM, Zigbee, CDMA2000 EV-DO, and RFID are being integrated for establishing the interconnection between bins and server. Moreover, node MCU and RKI-1451 has been implemented for communicating the sensory 
information over the internet. Additionally, we have considered one more parameter, i.e., customized prototype. Generally, the customized prototype allows the researchers to the design and implement a hardware according to requirements. A customized prototype reduces the infrastructure and time because the prototype developed is according to the study requirement. In order to design a customized prototype, from the controller unit to communication protocol, every aspect is being tested and simulated on design and simulation tools. Even the faults in the prototype can be quickly resolved within a short interval of time. So far, from the previous studies of IoT for SWM, we identified that the wireless communication protocol integrated for monitoring the bins experiences limitations due to the short-range transmission and high-power consumption. This problem is overcome by LoRa. With this advantage, various recent studies have embedded the LoRa communication within the end nodes for transmitting the data over long range. Low power consumption and long-range-based wireless communication is the requirement of the IoT network. Generally, in a mesh network and cellular network, the nodes must wake up and synchronize with the network and check the messages. This mechanism reduces the lifetime of a battery due to frequent energy consumption. LoRa (Long Range) is integrated with a pure ALOHA mechanism, and this will allow the network wake up automatically when there is a requirement to transmit the data. This factor enables longrange (LoRa) communication to consume low amounts of power during the transmission of the data. The studies in Table 9 address the profitability of implementing long-range LoRa communication for the waste management system. The customized prototype enables the researchers and users to design the prototype according to their requirements of the study. The cost-effective and energy-saving devices can be executed in customization.

Table 9. LoRa (Long Range)-based IoT SWM.

\begin{tabular}{|c|c|c|c|c|}
\hline Study & Objective & Controller & Sensors & Customized Prototype \\
\hline [116] & $\begin{array}{l}\text { Monitoring the bins and } \\
\text { optimizing waste collection. }\end{array}$ & SAM L21 & $\begin{array}{l}\text { Ultrasonic, load cell, and } \\
\text { temperature }\end{array}$ & Yes \\
\hline [117] & Monitoring the level in the bins. & Atmega 328P & Ultrasound & Yes \\
\hline [118] & $\begin{array}{l}\text { Monitoring the level and } \\
\text { classification of waste. }\end{array}$ & Arduino Uno & Ultrasonic sensor & No \\
\hline [138] & $\begin{array}{l}\text { Monitoring the level and } \\
\text { detection of fire in the bins. }\end{array}$ & ATMega328P & $\begin{array}{l}\text { Ultrasonic and } \\
\text { temperature sensor }\end{array}$ & Yes \\
\hline [139] & $\begin{array}{l}\text { Monitoring the level and } \\
\text { predicting the waste level. }\end{array}$ & $\mathrm{N} / \mathrm{A}$ & Ultrasonic sensor & No \\
\hline
\end{tabular}

Figure 9 illustrates the LoRa-based IoT architecture of SWM that are implemented in the recent studies. LoRa is embedded in the " $n$ " number of sensor nodes for transmitting the sensory data. The sensory data transmits to the gateway, where the internet connectivity is available for logging the data into the cloud server. Sensor nodes utilize the LoRa frequency band for transmitting the data to the gateway. The gateway is integrated into the LoRa network and IEEE 802.11 Wi-Fi/3G/4G for receiving the data from the sensor nodes and communicating the data to the cloud server. The cloud server computes the data, and it stores the data. Finally, LoRa (Long Range) is an optimal wireless communication technology for implementing IoT-based SWM. 


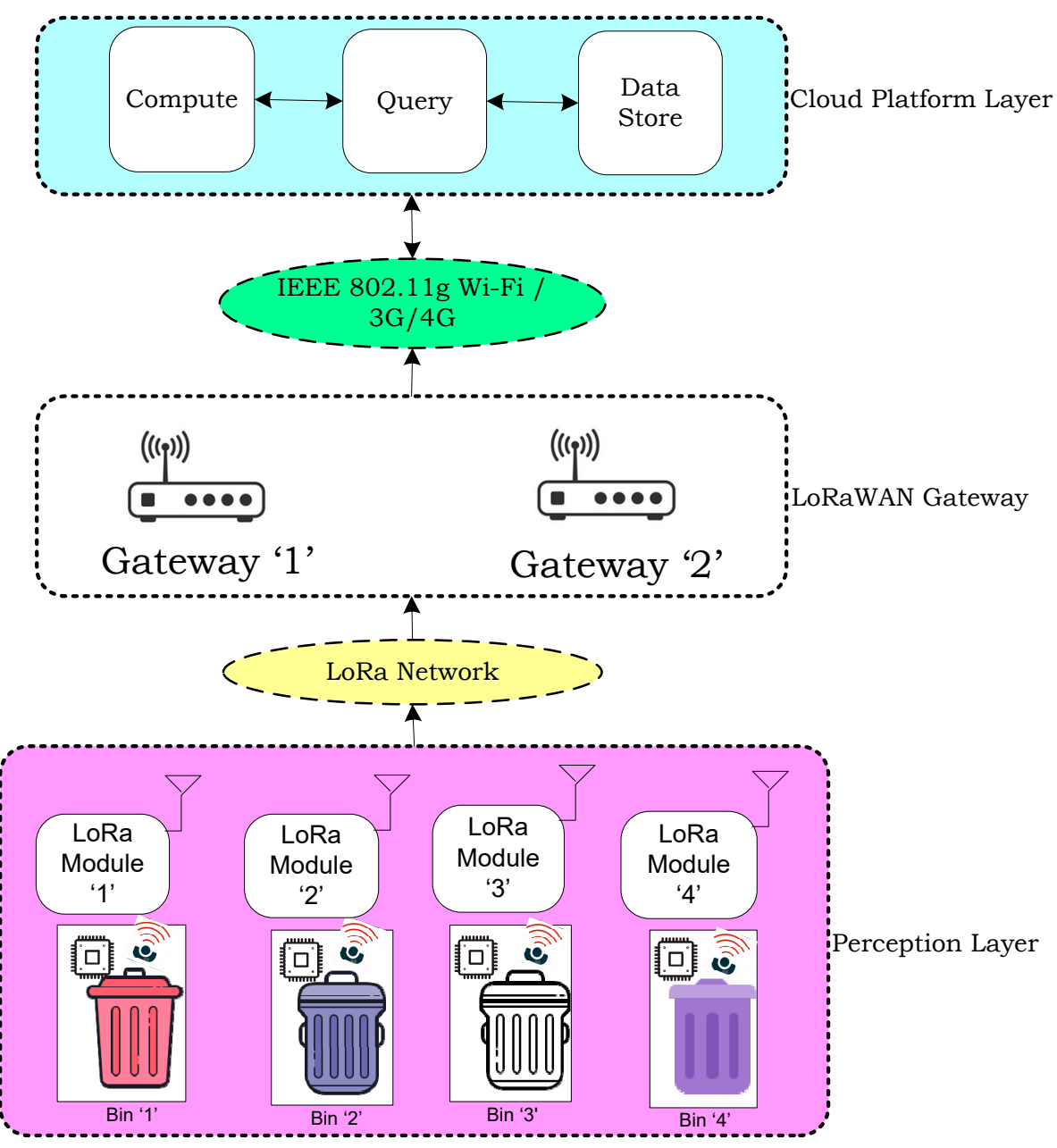

Figure 9. LoRa (Long Range)-based IoT architecture for waste management.

\subsection{Blockchain for SWM}

Blockchain technology is also represented as distributed ledger technology [140]. Blockchain is not merely the modern sort of global internet technology but also the new kind of supply chain that integrates hash algorithm, cryptography, and peer-to-peer network [141]. Decentralization, immutability, and transparency are the unique features of blockchain technology. These unique features of blockchain have enabled the implementation of blockchain in various fields, namely, energy, agriculture, manufacturing, medicine, etc., for enhancing the security to the data and executing secure transactions [142]. Generally, SWM lacks proper documentation regarding waste generation, collection, and recycling $[143,144]$. Here, blockchain technology assists the municipal authorities in allowing the distinct participants, customers, municipal authorities, inspector, contractor, police, and admins of SWM access on the same network for maintaining transparency.

- Customer-one who uses the blockchain platform for placing waste collection request.

- Municipality Authority-one who places the request of waste collection on the behalf of the customer.

- Inspector-one who visits the assigned site for inspection purpose.

- Contractors-one who is responsible for waste collection and management operations.

- Police-one who is responsible for checking the legal formalities involved in waste transportation.

- Admins-those who operate the waste management system as well as the experimental conclusions that can be drawn. 
The different holders in this blockchain payment process are customer, clerk, and municipality officer. Here, the clerk and municipality officer come under administration. At first, the customer needs to place a waste collection request through a mobile device, and then this request will then be received by the clerk for further processing. At the XOR junction, the clerk will be receiving requests from many customers. Figure 10 presents the blockchain-based payment process for waste management. The clerk receives the request, and here, the clerk verifies whether the request needs to be inspected or not. If there is a need to inspect the waste site (YES), the request will be sent to the respective municipal inspector to inspect the land filling site. If there is no need for inspecting (NO) the land filling site, then the payment process initiates for the customer waste collection request. The municipal inspector receives the request on a mobile device for checking out the waste filling site, and this inspector visits and verifies the waste filling site. After checking out the waste filling site, the municipal inspector initiates the payment process for the customer to pay for their waste collection request. Each and every payment detail of the customer's waste request will be reflected in their account. At every parallel junction (Green), multiple requests can be placed at a time. The payment is credited into different accounts for different days. Each activity in this flow diagram is available with everyone who is part of the payment process. 


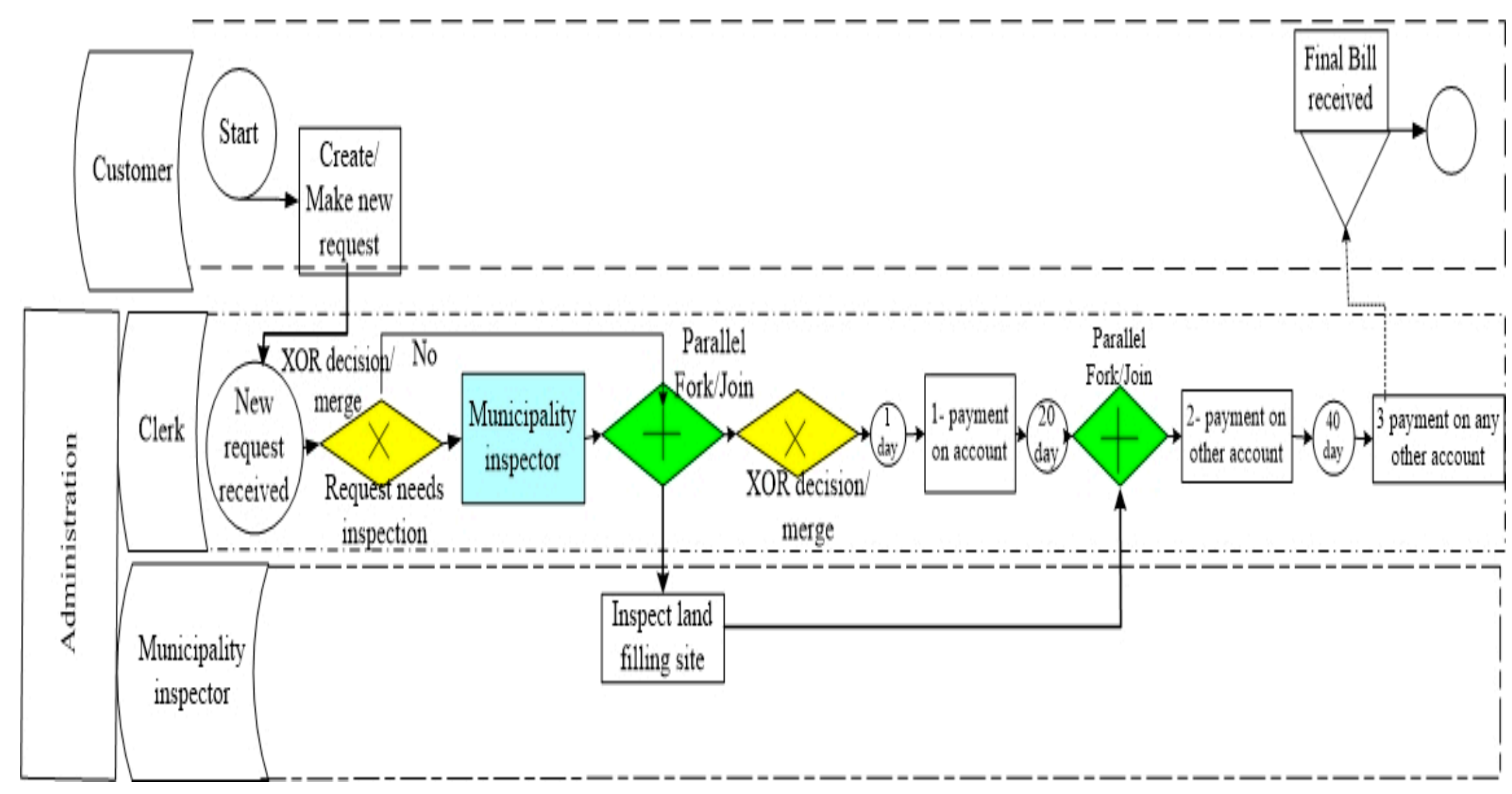

Figure 10. Blockchain based payment process for SWM. 


\section{Results}

In this section, we present the overall results that are obtained through the review. The results of each technology are discussed below.

- The geo-spatial technologies in the SWM have been employed for the following functions such as selection of dumping site, route optimization, bin allocation, groundwater risk assessment, and optimal route selection. These technologies have made it possible to make intelligent decisions from models and maps. However, the implementation of geo-spatial technologies is expensive, since to analyse different attributes of the image, it needs to be repetitively analysed. In addition, high storage capacity and high processing power are required to implement these technologies.

- Wireless data acquisition technology overcomes the limitations of geo-spatial technology because it obtains information within a limited memory and requires low processing power to process. In SWM, wireless data acquisition technology is widely implemented for the functions of waste collection, waste sorting, and level monitoring with optical sensors, infrared sensors, and ultrasonic sensors. A camera in the SWM is utilized for waste classification, identification of bin, and monitoring the dumping site.

- Wireless data communication technology supports the wireless data acquisition technology to transmit the acquisition data from one location to another. The selection of wireless data communication technology plays a crucial role in the SWM, as the sensor nodes deployed in the bins are powered by battery. The energy consumption by the sensor node is primarily due to the wireless communication protocol. Thus, selection of low-power-consumption wireless communication protocol with long-range transmission plays a crucial role. Currently, LoRa communication protocol is implemented in SWM for long-range transmission.

- In the current scenario, the advancement in wireless data acquisition and data communication technology empower the implementation of IoT for real monitoring of the activities involved in SWM. IoT, along with a cloud server, visualizes the sensor data on a graphical user interface, and distinct analytics are also applied to the sensor data available on the cloud server.

- Blockchain technology is a de-centralized and distributed ledger, where the data is encrypted and decrypted with a hashing algorithm and public key cryptography. In SWM, the blockchain technology is utilized to implement the digitalized documentation of activities such as waste generation, waste collection, and recycling. Every individual of the SWM is able to visualize the data in distributed ledger format. In addition, the circular economy model can be implemented in SWM to process the transactions.

\section{Discussion}

Waste management is one of the vital units that enables us to maintain urban cities clean and green. To maintain a clean and green environment in urban cities, implementing a waste management system should be adequate. Generally, the municipal authorities follow the door-to-door collection procedure for collecting waste in many areas. Here, the transportation cost is rising, and the transport unit visits the same area where the generation of waste is too low. Many researchers have proposed different mechanisms and technologies that have transformed the traditional waste management system into the intelligent waste management system. Still, they are in need of enhancement in the waste management system for effective collection and management. The enhancement in the waste management system will be addressed in different parameters as follows.

\subsection{Communication Range and Power Consumption}

Wireless communication protocol plays a crucial role for wireless monitoring of the bins from a remote location. In waste management, the end nodes are the primary source 
for transmitting the data of the bins. End nodes are the integration of sensors, actuators, a communication protocol, and a power source. Many studies have embedded the battery as a power source for the end nodes. As end nodes are energy constraint devices, there is a need for selecting the long-range and low-power-consumption communication protocol for the transmission of the data. GSM/GPRS wireless communication protocol is integrated into the many studies for communicating the status of the bins. Even though GSM/GPRS transmits the data to the long range, it consumes high amounts of power. With this factor, researchers have replaced GSM/GPRS with wireless personal network (WPAN) technologies such as ZigBee and Bluetooth for the transmission of the sensory data. Practically, the bins are in a different location far away from the municipal authority. However, the transmission range of these two wireless communication technologies is limited to $100 \mathrm{~m}$. The creation of a mesh network for monitoring leads to the interruption in the transmission of the data. The limitation of short range in WPAN and high-power consumption in GSM/GPRS triggered the researchers to look for feasible wireless communication technology. LoRa (Long Range) wireless communication overcomes the limitations in the previous wireless technologies that have been implemented in the waste management system for monitoring the bins. The pure ALOHA mechanism in the LoRa network enables low power consumption for transmission of the data. LoRa implementation the waste management has enhanced the monitoring of the bins in terms of transmission range and energy.

\subsection{Integration of IoT}

In waste management, the real monitoring of the threshold level of the bins is a necessary element for avoiding the overflow of garbage from the bins. Real-time monitoring of the bins is achieved by integrating the Internet of Things (IoT) in waste management. IoT connects and monitors the bins through internet protocol (IP), and additionally, the cloud server stores the real-time sensory data continuously. Data analytics tools can be implemented on the sensory data that are available in the cloud server for analysing the waste generation pattern of a different location at distinct time intervals. Google Cloud server (GCP), Thingspeak server, Amazon Web server, and Microsoft Azure server are different platforms that are available for municipal authorities to monitor the bins in real time. In our analysis, IoT in the waste management system is implemented for monitoring the threshold level and collection of waste. Recent studies of IoT-based waste management systems started focusing on the classification of the waste. For achieving the classification, one researcher implemented an AI-based object detection model and another implemented camera-based technology. The integration of IoT has brought smartness and intelligence to the waste management system.

\subsection{Local-Network- and Gateway-Based Architecture}

In many studies, the IoT-based architecture that is proposed for waste management system increases the infrastructure cost. IEEE 802.11-based wireless communication is embedded in the end nodes for logging the data to the cloud server via internet protocol (IP) as shown in Figure 8. The limitation of this kind of architecture is that a router needs to be installed for providing internet to every end node. Unavailability of internet connectivity to this architecture leads to failure. Concerning Figure 9, embedding the LoRa module in every sensory node of the bin increases the infrastructure cost. However, these limitations can be overcome by proposing a local-network- and gateway-based IoT architecture for the waste management system.

We suggest a local network and gateway based on the IoT-based waste management system. Figure 11 illustrates the architecture, which is an integration of IEEE 802.15.4 ZigBee and IEEE 802.11, i.e., LoRa. Both ZigBee and LoRa (Long Range) utilize the ISM (industrial, scientific, and medicine) band to transmit the data. The ISM band is an open license band, and there is no requirement for additional expenditure to transmit the data. However, deployment of LoRa in sensor nodes increases the infrastructure; here, we suggest a local network to be established between the sensor nodes and gateway for 
reducing the infrastructure cost. A local network is an integration of ZigBee and LoRa communication. Zigbee-based sensor nodes transmit the data from the sensor node to the local network. The local network receives the data via the ZigBee network and transmits the data to the gateway via the LoRa (Long Range) network. The gateway act as a bridge for transmitting the data from the end node to the cloud server. The gateway integrates LoRa (Long Range) and IEEE 802.11 wireless protocol for receiving the data from the local network and transmitting the data to the cloud server via internet protocol (IP). This kind of architecture overcomes the connectivity failure and is cost-effective.
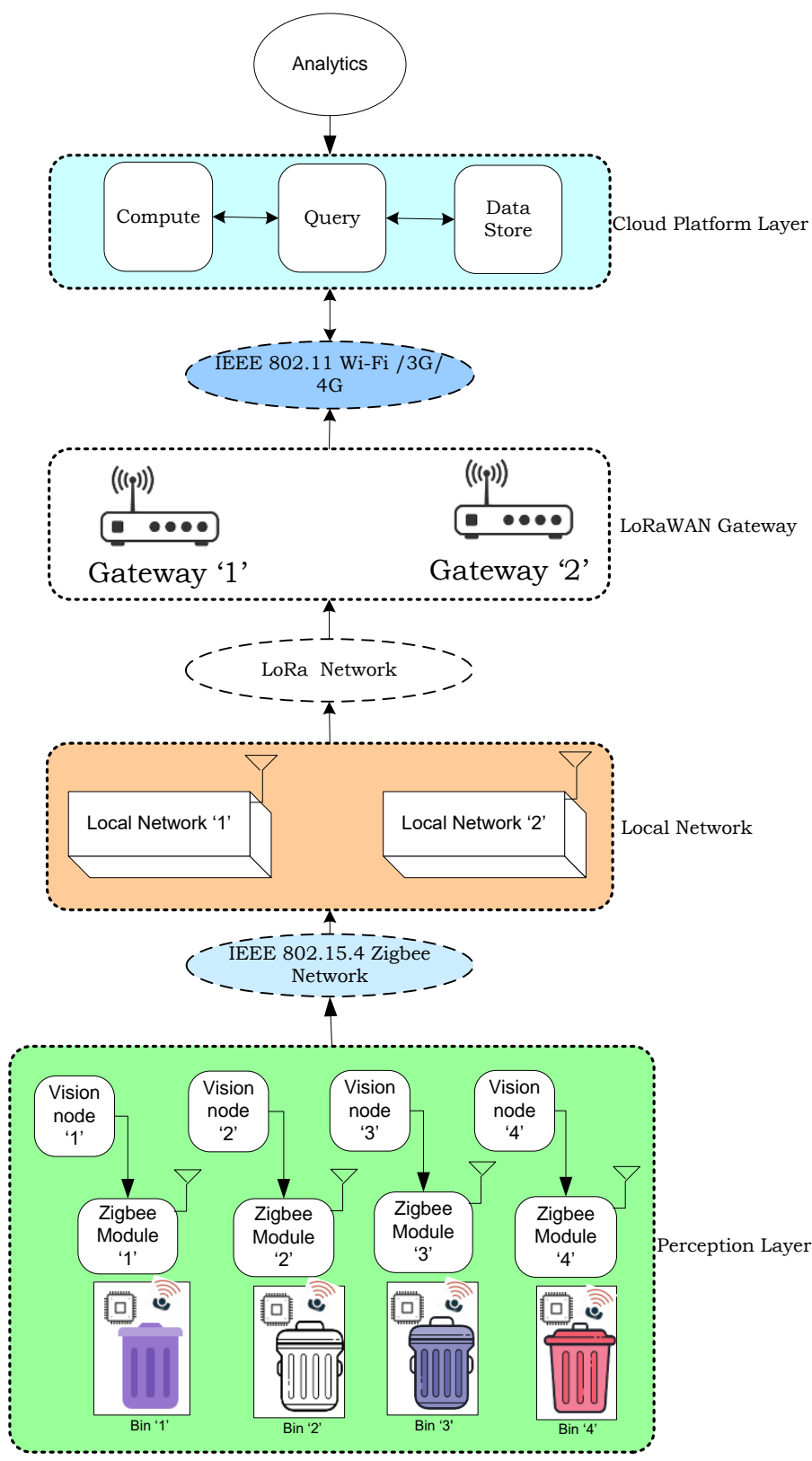

Figure 11. Local-network- and vision-node-based IoT architecture for SWM.

\subsection{Customization of a Prototype}

A vision-based node in the SWM enables the authorities to monitor the outdoor environment of the bins. The vision node continuously monitors and records the activities around the bins, and it is shown in the Figure 11. Visuals capturing every disposal collection assist the municipal authorities in checking whether the disposal collection is processing efficiently or not. The captured data can be utilized for prediction of classification of waste, 
waste generation pattern, and amount of waste generation by applying the AI techniques. If the vision node is embedded with AI computing, then the node is capable of making decisions by itself. Security and authentication of the bins will be enhanced.

\subsection{Waste to Money}

Citizens have responsibility for reducing the amount of waste generated and its effects on the environment. Technologies, alone, cannot accomplish efficient waste management, and the individual should be part of it. We suggest a waste-to-money model as the optimal solution for engaging citizens in reducing waste. The waste-to-money model is a concept in which money can be generated to every individual for the disposing of the waste. The money is generated to the individual based on the quantity of waste disposed. However, transparency and security come into the act for implementing this model precisely. Here, the blockchain-based de-centralized application can be established for performing the transactions. Blockchain technology is ledger-based technology in which data tampering is not possible due to hash cryptography. Blockchain technology also provides transparency and security for implementing the waste to money model.

\section{Novelty of the Study}

In this section, the discussion of the novelty of the study compared to previous studies in the same field is presented as follows:

- In this study, we provided a detailed investigation of various geo-spatial technologies, along with their significance, limitations, and applications for SWM. In addition, research on various wireless data acquisition, wireless data communication with the IoT, and blockchain is also presented in detail in this research. This study covers the entire ICT technology from geo-spatial to blockchain.

- In the IoT for SWM, this study discussed two different architectures implemented in the SWM for real-time monitoring. This section clearly describes the implications and limitations of the two different architectures.

- In the blockchain for SWM, the study presented a pictorial diagram that provides the path for the implementation of blockchain to enhance the digital documentation during entire cycle of SWM.

- In the discussion section, the study suggested an IoT-based architecture for scalable community. This architecture is suggested to overcome the connectivity and power consumption during implementation of IoT network in an outdoor environment. Moreover, this study highlighted the waste-to-money model with blockchain and customization of the prototype.

\section{Conclusions}

Waste management plays a significant role in maintaining a clean and green environment by managing waste effectively and waste-management-concerning issues in smart cities. The objective of the green environment is to enhance the quality and reliability of environment assessment by using digital technology, i.e., IoT. Cloud-based IoT collects, evaluates, and processes data in real time to assist municipalities, corporations, and residents in making better decisions that enhance their quality of life. IoT is the sub-set of ICT, and ICT is the backbone of the smart city that is utilized for improving the quality of life. This study analysed the geo-spatial, wireless data acquisition and wireless data communication technologies, and IoT implementation in SWM. Each technology is summarized in tabular form with its function and technical specifications. The significance of AI and blockchain for SWM is discussed in this study. Finally, we have suggested a local network and architecture model, customized prototype, vision node, and blockchain-based waste-to-money model for establishing an effective environment in the SWM.

Author Contributions: S.V.A., R.S. and A.G. made contributions to conception and manuscript writing; A.S.A. and S.S.A. examined and supervised this research and outcomes; M.R. and D.P. 
revised and polished the manuscript. All authors have read and agreed to the published version of the manuscript.

Funding: This research was supported by Taif University Research Supporting Project number (TURSP-2020/311), Taif University, Taif, Saudi Arabia.

Conflicts of Interest: The authors declare no conflict of interest.

\section{References}

1. The Weight of Cities Resource Panel. Available online: https://www.resourcepanel.org/reports/weight-cities (accessed on 10 August 2021).

2. ONU. World Population Prospects 2019; United Nations: New York, NY, USA, 2019; Volume 141.

3. Global Waste to Grow by 70 Percent by 2050 Unless Urgent Action is Taken: World Bank Report. Available online: https: / / www.worldbank.org/en/news/press-release/2018/09/20/global-waste-to-grow-by-70-percent-by-2050-unlessurgent-action-is-taken-world-bank-report (accessed on 23 October 2020).

4. Planning Commission Report. Reports of the Taskforce on Waste to Energy (Vol-I). 2014. Available online: http: //planningcommission.nic.in/reports/genrep/rep_wte1205.pdf (accessed on 23 October 2020).

5. Cheng, H.; Hu, Y. Municipal solid waste (MSW) as a renewable source of energy: Current and future practices in China. Bioresour. Technol. 2010, 101, 3816-3824. [CrossRef] [PubMed]

6. World Bank Group. The Solid Waste Management Sector; Department of Economic Affairs: New Delhi, India, 2009.

7. Kumar, S.; Smith, S.R.; Fowler, G.; Velis, C.; Kumar, S.J.; Arya, S.; Rena Kumar, R.; Cheeseman, C. Challenges and opportunities associated with waste management in India. R. Soc. Open Sci. 2017, 4, 160764. [CrossRef]

8. Yazdani, M.; Kabirifar, K.; Fathollahi-Fard, A.M.; Mojtahedi, M. Production scheduling of off-site prefabricated construction components considering sequence dependent due dates. Environ. Sci. Pollut. Res. 2021, 1-17. [CrossRef]

9. Tsai, F.M.; Bui, T.D.; Tseng, M.L.; Lim, M.K.; Hu, J. Municipal solid waste management in a circular economy: A data-driven bibliometric analysis. J. Clean. Prod. 2020, 275, 124132. [CrossRef]

10. Gholizadeh, H.; Fazlollahtabar, H.; Fathollahi-Fard, A.M.; Dulebenets, M.A. Preventive maintenance for the flexible flowshop scheduling under uncertainty: A waste-to-energy system. Environ. Sci. Pollut. Res. 2021, 1-20. [CrossRef] [PubMed]

11. Ramachandra, T.V.; Bharath, H.A.; Kulkarni, G.; Han, S.S. Municipal solid waste: Generation, composition and GHG emissions in Bangalore, India. Renew. Sustain. Energy Rev. 2018, 82, 1122-1136. [CrossRef]

12. Abdel-Shafy, H.I.; Mansour, M.S.M. Solid waste issue: Sources, composition, disposal, recycling, and valorization. Egypt. J. Pet. 2018, 27, 1275-1290. [CrossRef]

13. Nagpure, A.S. Assessment of quantity and composition of illegal dumped municipal solid waste (MSW) in Delhi. Resour. Conserv. Recycl. 2019, 141, 54-60. [CrossRef]

14. How Can India's Waste Problem See a Systemic Change? Economic and Political Weekly. Available online: https://www. epw.in/engage/article/institutional-framework-implementing-solid-waste-management-india-macro-analysis (accessed on 23 October 2020).

15. Kawai, K.; Huong, L.T.M. Key parameters for behaviour related to source separation of household organic waste: A case study in Hanoi, Vietnam. Waste Manag. Res. 2017, 35, 246-252. [CrossRef]

16. Solid Waste Management Rules Revised After 16 Years; Rules Now Extend to Urban and Industrial Areas: Javadekar. Available online: https:/ / pib.gov.in/newsite/PrintRelease.aspx?relid=138591 (accessed on 11 August 2021).

17. Saleh, H.E.-D.M. Introductory Chapter: Introduction to Hazardous Waste Management. In Management of Hazardous Wastes; InTech: London, UK, 2016. [CrossRef]

18. Datta, P.; Mohi, G.; Chander, J. Biomedical waste management in India: Critical appraisal. J. Lab. Physicians 2018, 10, 6-14. [CrossRef]

19. Ayilara, M.S.; Olanrewaju, O.S.; Babalola, O.O.; Odeyemi, O. Waste management through composting: Challenges and potentials. Sustainability 2020, 12, 4456. [CrossRef]

20. Rajendran, K.; Björk, H.; Taherzadeh, M.J. Borås, a zero waste city in Sweden. J. Dev. Manag. 2013, 1, 3-8.

21. THE 17 GOALS Sustainable Development. Available online: https://sdgs.un.org/goals (accessed on 15 March 2021).

22. Guerrero, L.A.; Maas, G.; Hogland, W. Solid waste management challenges for cities in developing countries. Waste Manag. 2013, 33, 220-232. [CrossRef] [PubMed]

23. Singh, A. An overview of the optimization modelling applications. J. Hydrol. 2012, 466, 167-182. [CrossRef]

24. Anagnostopoulos, T.; Zaslavsky, A.; Kolomvatsos, K.; Medvedev, A.; Amirian, P.; Morley, J.; Hadjieftymiades, S. Challenges and opportunities of waste management in IoT-enabled smart cities: A survey. IEEE Trans. Sustain. Comput. 2017, 2, 275-289. [CrossRef]

25. OECD Glossary of Statistical Terms-Information, Communication Technology (ICT) Goods Definition. Available online: https: / / stats.oecd.org/glossary/detail.asp?ID=6274 (accessed on 4 March 2021).

26. Lu, J.-W.; Chang, N.-B.; Liao, L. Environmental informatics for solid and hazardous waste management: Advances, challenges, and perspectives. Crit. Rev. Environ. Sci. Technol. 2013, 43, 1557-1656. [CrossRef] 
27. Vitorino de Souza Melaré, A.; Montenegro González, S.; Faceli, K.; Casadei, V. Technologies and decision support systems to aid solid-waste management: A systematic review. Waste Manag. 2017, 59, 567-584. [CrossRef] [PubMed]

28. Misra, D.; Das, G.; Chakrabortty, T.; Das, D. An IoT-based waste management system monitored by cloud. J. Mater. Cycles Waste Manag. 2018, 20, 1574-1582. [CrossRef]

29. Pardini, K.; Rodrigues, J.J.; Kozlov, S.A.; Kumar, N.; Furtado, V. IoT-based solid waste management solutions: A survey. J. Sens. Actuator Netw. 2019, 8, 5. [CrossRef]

30. Milla, K.A.; Lorenzo, A.; Brown, C. GIS, GPS, and remote sensing technologies in extension services: Where to start, what to know. J. Ext. 2005, 43, 1-8.

31. Ghose, M.K.; Dikshit, A.K.; Sharma, S.K. A GIS based transportation model for solid waste disposal—A case study on Asansol municipality. Waste Manag. 2006, 26, 1287-1293. [CrossRef]

32. Sisay, G.; Gebre, S.L.; Getahun, K. GIS-based potential landfill site selection using MCDM-AHP modeling of Gondar Town, Ethiopia. Afr. Geogr. Rev. 2021, 40, 105-124. [CrossRef]

33. Singh, A. Remote sensing and GIS applications for municipal waste management. J. Environ. Manag. 2019, 243, 22-29. [CrossRef] [PubMed]

34. Karimi, H.; Amiri, S.; Huang, J.; Karimi, A. Integrating GIS and multi-criteria decision analysis for landfill site selection, case study: Javanrood County in Iran. Int. J. Environ. Sci. Technol. 2019, 16, 7305-7318. [CrossRef]

35. Akhtar, M.; Hannan, M.A.; Begum, R.A.; Basri, H.; Scavino, E. Backtracking search algorithm in CVRP models for efficient solid waste collection and route optimization. Waste Manag. 2017, 61, 117-128. [CrossRef]

36. Hannan, M.A.; Akhtar, M.; Begum, R.A.; Basri, H.; Hussain, A.; Scavino, E. Capacitated vehicle-routing problem model for scheduled solid waste collection and route optimization using PSO algorithm. Waste Manag. 2018, 71, 31-41. [CrossRef]

37. Vu, H.L.; Bolingbroke, D.; Ng, K.T.W.; Fallah, B. Assessment of waste characteristics and their impact on GIS vehicle collection route optimization using ANN waste forecasts. Waste Manag. 2019, 88, 118-130. [CrossRef]

38. Vu, H.L.; Ng, K.T.W.; Fallah, B.; Richter, A.; Kabir, G. Interactions of residential waste composition and collection truck compartment design on GIS route optimization. Waste Manag. 2020, 102, 613-623. [CrossRef]

39. Rathore, P.; Sarmah, S.P.; Singh, A. Location-allocation of bins in urban solid waste management: A case study of Bilaspur city, India. Environ. Dev. Sustain. 2020, 22, 3309-3331. [CrossRef]

40. Farahbakhsh, A.; Forghani, M.A. Sustainable location and route planning with GIS for waste sorting centers, case study: Kerman, Iran. Waste Manag. Res. 2019, 37, 287-300. [CrossRef] [PubMed]

41. Khan, D.; Samadder, S.R. Allocation of solid waste collection bins and route optimisation using geographical information system: A case study of Dhanbad City, India. Waste Manag. Res. 2016, 34, 666-676. [CrossRef]

42. Erfani, S.M.H.; Danesh, S.; Karrabi, S.M.; Shad, R. A novel approach to find and optimize bin locations and collection routes using a geographic information system. Waste Manag. Res. 2017, 35, 776-785. [CrossRef]

43. Solano Meza, J.K.; Rodrigo-Ilarri, J.; Romero Hernández, C.P.; Rodrigo-Clavero, M.E. Analytical Methodology for the Identification of Critical Zones on the Generation of Solid Waste in Large Urban Areas. Int. J. Environ. Res. Public Health 2020, 17, 1196. [CrossRef]

44. Kariapper, R.K.A.R.; Pirapuraj, P.; Suhail Razeeth, M.S.; Nafrees, A.C.M.; Rameez, K.L.M. Smart Garbage Collection Using GPS Shortest Path Algorithm. In Proceedings of the 2019 IEEE Pune Section International Conference, PuneCon, Pune, India, 18-20 December 2019. [CrossRef]

45. Khan, F.I.; Gawade, A. Dynamic Routing for Waste Management using IoT for Cost-Efficient Service. In International Conference on Current Trends in Computer, Electrical, Electronics and Communication, CTCEEC 2017; IEEE: Piscataway, NJ, USA, 2018; pp. 222-230. [CrossRef]

46. Jino Ramson, S.R.; Jackuline Moni, D.; Alfred Kirubaraj, A.; Senith, S. Self-powered wireless sensor network framework to monitor bin level. J. Solid Waste Technol. Manag. 2007, 43, 295-304. [CrossRef]

47. Mojtahedi, M.; Fathollahi-Fard, A.M.; Tavakkoli-Moghaddam, R.; Newton, S. Sustainable vehicle routing problem for coordinated solid waste management. J. Ind. Inf. Integr. 2021, 23, 100220. [CrossRef]

48. Steyn, L.J.; Willemse, E.J. Using Vehicle GPS Data to Infer Offloading Times of Waste Collection Vehicles at Transfer Stations. In Proceedings of the 2018 International Conference on Advances in Big Data, Computing and Data Communication Systems, icABCD, Durban, South Africa, 6-7 August 2018. [CrossRef]

49. Chakole, S.; Khadse, P.; Shinganjude, S.; Pimple, P.; Shahane, S.; Mokhale, S. Real Time Smart City Garbage Collection and Monitoring System Using GSM and GPS. Int. Res. J. Eng. Technol. 2017, 4, 1226-1229.

50. Tarone, A.V.; Katgube, A.A.; Shendre, H.H.; Ghugal, R.P.; Bobade, P.N.P. IOT Based Smart Garbage Monitoring System Using ESP8266 with GPS Link. Int. Res. J. Eng. Technol. 2018, 5, 5-6.

51. Schowengerdt, R.A. Remote Sensing: Models and Methods for Image Processing. Available online: https://books.google.co.in/ books?hl=en\&lr=\&id=KQXNaDH0X-IC\&oi=fnd\&pg=PP1\&ots=sogWMLD9KG\&sig=fUMALhqfpyKRDk3e5PgN6WhA7rQ\& redir_esc $=\mathrm{y} \# \mathrm{v}=$ onepage \&q\&f=false (accessed on 26 October 2020).

52. Hannan, M.A.; Arebey, M.; Begum, R.A.; Basri, H. Radio Frequency Identification (RFID) and communication technologies for solid waste bin and truck monitoring system. Waste Manag. 2011, 31, 2406-2413. [CrossRef] [PubMed]

53. Nguyen-Trong, K.; Nguyen-Thi-Ngoc, A.; Nguyen-Ngoc, D.; Dinh-Thi-Hai, V. Optimization of municipal solid waste transportation by integrating GIS analysis, equation-based, and agent-based model. Waste Manag. 2017, 59, 14-22. [CrossRef] 
54. Lotfi, S.; Habibi, K.; Koohsari, M.J. Integrating GIS and fuzzy logic for urban solid waste management (a case study of Sanandaj city, Iran). Pak. J. Biol. Sci. 2007, 10, 4000-4007. [CrossRef] [PubMed]

55. Vijay, R.; Gautam, A.; Kalamdhad, A.; Gupta, A.; Devotta, S. GIS-based locational analysis of collection bins in municipal solid waste management systems. J. Environ. Eng. Sci. 2008, 7, 39-43. [CrossRef]

56. Tavares, G.; Zsigraiova, Z.; Semiao, V.; Carvalho, M.G. Optimisation of MSW collection routes for minimum fuel consumption using 3D GIS modelling. Waste Manag. 2009, 29, 1176-1185. [CrossRef]

57. Fan, X.; Zhu, M.; Zhang, X.; He, Q.; Rovetta, A. Solid Waste Collection Optimization Considering Energy Utilization for Large City Area. In Proceedings of the International Conference on Logistics Systems and Intelligent Management (ICLSIM), Harbin, China, 9-10 January 2010; Volume 3, pp. 1905-1909.

58. Chonattu, J.; Prabhakar, K.; Pillai, H.P.S. Geospatial and statistical assessment of groundwater contamination due to landfill leachate-A case study. J. Water Resour. Prot. 2016, 8, 121-134. [CrossRef]

59. Karadimas, N.V.; Loumos, V.G. GIS-based modelling for the estimation of municipal solid waste generation and collection. Waste Manag. Res. 2008, 26, 337-346. [CrossRef]

60. Anghinolfi, D.; Paolucci, M.; Robba, M.; Taramasso, A.C. A dynamic optimization model for solid waste recycling. Waste Manag. 2013, 33, 287-296. [CrossRef]

61. Chalkias, C.; Lasaridi, K. A GIS based model for the optimisation of municipal solid waste collection: The case study of Nikea, Athens, Greece. Technology 2009, 1, 11-15.

62. Vu, H.L.; Ng, K.T.W.; Bolingbroke, D. Parameter interrelationships in a dual phase GIS-based municipal solid waste collection model. Waste Manag. 2018, 78, 258-270. [CrossRef]

63. Ferronato, N.; Preziosi, G.; Gorritty Portillo, M.A.; Guisbert Lizarazu, E.G.; Torretta, V. Assessment of municipal solid waste selective collection scenarios with geographic information systems in Bolivia. Waste Manag. 2020, 102, 919-931. [CrossRef]

64. Okot, P.; Ogao, P.J.; Abandu, J. Site selection model for urban solid waste disposal management using GIS and remote sensing: A case of Gulu Municipality. Int. J. Environ. Waste Manag. 2019, 24, 405-436. [CrossRef]

65. Ahmad, I.S.; Kim, D.H. Quantum GIS Based Descriptive and Predictive Data Analysis for Effective Planning of Waste Management. IEEE Access 2020, 8, 46193-46205. [CrossRef]

66. Town, B.; Asefa, B.; Mindahun, W. Suitable Solid Waste Disposal Site Selection Using Geographical Information System: A Case of Debre Markos Town, Ethiopia. J. Environ. Earth Sci. 2020, 7, 17-23. [CrossRef]

67. Amal, L.; Son, L.H.; Chabchoub, H.; Lahiani, H. Analysis of municipal solid waste collection using GIS and multi-criteria decision aid. Appl. Geomat. 2020, 12, 193-208. [CrossRef]

68. Apaydin, O.; Gonullu, M.T. Route optimization for solid waste collection: Trabzon (Turkey) case study. Glob. NEST J. 2007, 9, 6-11.

69. Wilson, B.G.; Vincent, J.K. Estimating waste transfer station delays using GPS. Waste Manag. 2008, 28, 1742-1750. [CrossRef]

70. O'Connor, M.C. Routeware launches RFID solution for waste haulers: The system employs low-frequency RFID interrogators on trash-collection trucks to identify tagged waste and recycling containers, as well as track the recycling efforts of the residents they serve. RFID J. 2008. Available online: https:/ / www.studio98test.com/ahmad-test/routeware-launches-rfid-solution-for-wastehaulers (accessed on 26 October 2020).

71. Rovetta, A.; Xiumin, F.; Vicentini, F.; Minghua, Z.; Giusti, A.; Qichang, H. Early detection and evaluation of waste through sensorized containers for a collection monitoring application. Waste Manag. 2009, 29, 2939-2949. [CrossRef]

72. Nielsen, I.; Lim, M.; Nielsen, P. Optimizing Supply Chain Waste Management through the Use of RFID Technology. In Proceedings of the 2010 IEEE International Conference on RFID-Technology and Applications, RFID-TA, Guangzhou, China, 17-19 June 2010; pp. 296-301. [CrossRef]

73. Mussa, A.; Suryabhagavan, K.V. Solid waste dumping site selection using GIS-based multi-criteria spatial modeling: A case study in Logia town, Afar region, Ethiopia. Geol. Ecol. Landsc. 2021, 5, 186-198. [CrossRef]

74. Mundhe, N.; Jaybhaye, R.; Dorik, B. Assessment of Municipal Solid Waste Management of Pune City using Geospatial Tools. Int. J. Comput. Appl. 2014, 100, 24-32. [CrossRef]

75. Zeeshan, S.; Shahid, Z.; Khan, S.; Shaikh, F.A. Solid Waste Management in Korangi District of Karachi using GPS and GIS: A Case study. In Proceedings of the 7th International Conference on Computer and Communication Engineering (ICCCE), Kuala Lumpur, Malaysia, 19-20 September 2018; pp. 1-4.

76. Yang, K.; Zhou, X.N.; Yan, W.A.; Hang, D.R.; Steinmann, P. Landfills in Jiangsu province, China, and potential threats for public health: Leachate appraisal and spatial analysis using geographic information system and remote sensing. Waste Manag. 2008, 28, 2750-2757. [CrossRef]

77. Adeofun, C.O.; Achi, H.A.; Ufoegbune, G.C.; Gbadebo, A.M.; Oyedepo, J.A. Application of remote sensing and geographic information system for selecting dumpsites and transport routes in Abeokuta, Nigeria. Coler. Proc. 2012, 1, $264-278$.

78. Karsauliya, S. Application of Remote Sensing and GIS in Solid Waste Management: A Case Study of Surroundings of River Yamuna, India. Int. J. Environ. Eng. Manag. 2013, 4, 593-604.

79. Gautam, S.; Brema, J.; Dhasarathan, R. Spatio-temporal estimates of solid waste disposal in an urban city of India: A remote sensing and GIS approach. Environ. Technol. Innov. 2020, 18, 100650. [CrossRef]

80. Vambol, S.; Vambol, V.; Sundararajan, M.; Ansari, I. The nature and detection of unauthorized waste dump sites using remote sensing. Ecol. Quest. 2019, 30, 43-55. [CrossRef] 
81. Richter, A.; Ng, K.T.W.; Karimi, N. A data driven technique applying GIS, and remote sensing to rank locations for waste disposal site expansion. Resour. Conserv. Recycl. 2019, 149, 352-362. [CrossRef]

82. Cusworth, D.H.; Duren, R.M.; Thorpe, A.K.; Tseng, E.; Thompson, D.; Guha, A.; Miller, C.E. Using remote sensing to detect, validate, and quantify methane emissions from California solid waste operations. Environ. Res. Lett. 2020, 15, 054012. [CrossRef]

83. Faccio, M.; Persona, A.; Zanin, G. Waste collection multi objective model with real time traceability data. Waste Manag. 2011, 31, 2391-2405. [CrossRef]

84. Fraden, J. Handbook of Modern Sensors: Physics, Designs, and Applications; Springer Science \& Business Media: Berlin/Heidelberg, Germany, 2004.

85. Cavdar, K.; Koroglu, M.; Akyildiz, B. Design and implementation of a smart solid waste collection system. Int. J. Environ. Sci. Technol. 2016, 13, 1553-1562. [CrossRef]

86. Al Mamun, M.A.; Hannan, M.A.; Hussain, A.; Basri, H. Integrated sensing systems and algorithms for solid waste bin state management automation. IEEE Sens. J. 2015, 15, 561-567. [CrossRef]

87. Huang, J.; Pretz, T.; Bian, Z. Intelligent Solid Waste Processing Using Optical Sensor based Sorting Technology. In Proceedings of the 3rd International Congress on Image and Signal Processing, Yantai, China, 16-18 October 2010; Volume 4, pp. $1657-1661$.

88. Sundas, A.; Panda, S.N. IoT Based Integrated Technologies for Garbage Monitoring System. In Proceedings of the 8th International Conference on Reliability, Infocom Technologies and Optimization (Trends and Future Directions) (ICRITO), Noida, India, 4-5 June 2020; pp. 57-62.

89. Arebey, M.; Hannan, M.A.; Basri, H.; Begum, R.A.; Abdullah, H. Solid Waste Monitoring System Integration based on RFID, GPS and Camera. In Proceedings of the International Conference on Intelligent and Advanced Systems, Taipei, Taiwan, 18-22 October 2010; pp. 1-5.

90. Wagland, S.T.; Veltre, F.; Longhurst, P.J. Development of an image-based analysis method to determine the physical composition of a mixed waste material. Waste Manag. 2012, 32, 245-248. [CrossRef]

91. Thanawala, D.; Sarin, A.; Verma, P. An Approach to Waste Segregation and Management Using Convolutional Neural Networks. In Proceedings of the International Conference on Advances in Computing and Data Sciences, Valletta, Malta, 24-25 April 2020; pp. 139-150.

92. Nagori, M.; Jachak, R.S.; Chaudhari, P.P. A Framework for Segregating Solid Waste by Employing the Technique of Image Annotation. In Proceedings of the Second International Conference on Advanced Computational and Communication Paradigms (ICACCP), Gangtok, India, 25-28 February 2019; pp. 1-6.

93. Vo, A.H.; Vo, M.T.; Le, T. A novel framework for trash classification using deep transfer learning. IEEE Access 2019, 7, 178631-178639. [CrossRef]

94. Liu, Y.; Fung, K.-C.; Ding, W.; Guo, H.; Qu, T.; Xiao, C. Novel Smart Waste Sorting System based on Image Processing Algorithms: SURF-BoW and Multi-class SVM. Comput. Inf. Sci. 2018, 11, 35-49. [CrossRef]

95. Gundupalli, S.P.; Hait, S.; Thakur, A. A review on automated sorting of source-separated municipal solid waste for recycling. Waste Manag. 2017, 60, 56-74. [CrossRef] [PubMed]

96. Chu, Y.; Huang, C.; Xie, X.; Tan, B.; Kamal, S.; Xiong, X. Multilayer hybrid deep-learning method for waste classification and recycling. Comput. Intell. Neurosci. 2018, 2018, 5060857. [CrossRef] [PubMed]

97. Singh, A.; Aggarwal, P.; Arora, R. IoT based Waste Collection System Using Infrared Sensors. In Proceedings of the 5th International Conference on Reliability, Infocom Technologies and Optimization (Trends and Future Directions) (ICRITO), Noida, India, 7-9 September 2016; pp. 505-509.

98. Deka, K.; Goswami, K. IoT-Based Monitoring and Smart Planning of Urban Solid Waste Management. In Lecture Notes in Electrical Engineering; Springer: Singapore, 2018; Volume 462, pp. 895-905. [CrossRef]

99. Ali, N.; Awais, M.; Muzammul, M.; Zafar, A. Intelligent System for Garbage collection: IoT technology with Ultrasonic sensor and Arduino Mega. Int. J. Comput. Sci. Netw. 2018, 18, 102.

100. Memon, S.K.; Shaikh, F.K.; Mahoto, N.A.; Memon, A.A. IoT based Smart Garbage Monitoring \& Collection System Using WeMos \& Ultrasonic Sensors. In Proceedings of the 2nd International Conference on Computing, Mathematics and Engineering Technologies (iCoMET), Sukkur, Pakistan, 30-31 January 2019; pp. 1-6.

101. Addabbo, T.; Fort, A.; Mecocci, A.; Mugnaini, M.; Parrino, S.; Pozzebon, A.; Vignoli, V. A LoRa-based IoT Sensor Node for Waste Management Based on a Customized Ultrasonic Transceiver. In Proceedings of the IEEE Sensors Applications Symposium (SAS), Sophia Antipolis, France, 11-13 March 2019; pp. 1-6.

102. Chaudhari, M.S.; Patil, B.; Raut, V. IoT based Waste Collection Management System for Smart Cities: An Overview. In Proceedings of the 3rd International Conference on Computing Methodologies and Communication (ICCMC), Erode, India, 27-29 March 2019; pp. 802-805.

103. Durrani, A.M.F.; Rehman, A.U.; Farooq, A.; Meo, J.A.; Sadiq, M.T. An Automated Waste Control Management System (AWCMS) by Using Arduino. In Proceedings of the International Conference on Engineering and Emerging Technologies (ICEET), Lahore, Pakistan, 21-22 February 2019; pp. 1-6.

104. Vasagade, T.S.; Tamboli, S.S.; Shinde, A.D. Smart Solid Waste Collection and Management System. In Techno-Societal; Springer International Publishing: New York, NY, USA, 2020; pp. 663-671.

105. Hannan, M.A.; Arebey, M.; Begum, R.A.; Basri, H. An automated solid waste bin level detection system using a gray level aura matrix. Waste Manag. 2012, 32, 2229-2238. [CrossRef] [PubMed] 
106. Szoke-Sieswerda, J.M. A Vision System for Automating Municipal Waste Collection; Western Libraries: London, UK, 2014.

107. Yu, Y. A Computer Vision Based Detection System for Trash Bins Identification during Trash Classification. J. Phys. Conf. Ser. 2020, 1617, 12015. [CrossRef]

108. Rad, M.S.; von Kaenel, A.; Droux, A.; Tieche, F.; Ouerhani, N.; Ekenel, H.K.; Thiran, J.P. A Computer Vision System to Localize and Classify Wastes on the Streets. In International Conference on Computer Vision Systems; Springer: Berlin/Heidelberg, Germany, 2017; pp. 195-204.

109. Vishnu, S.; Ramson, S.R.; Senith, S.; Anagnostopoulos, T.; Abu-Mahfouz, A.M.; Fan, X.; Srinivasan, S.; Kirubaraj, A.A. IoT-Enabled Solid Waste Management in Smart Cities. Smart Cities 2021, 4, 1004-1017. [CrossRef]

110. Chinnathurai, B.M.; Sivakumar, R.; Sadagopan, S.; Conrad, J.M. Design and Implementation of a Semi-Autonomous Waste Segregation Robot. In Proceedings of the Conference Proceedings-IEEE SOUTHEASTCON, Norfolk, VA, USA, 30 March-3 April 2016; Volume 2016. [CrossRef]

111. Yun, K.; Kwon, Y.; Oh, S.; Moon, J.; Park, J. Vision-based garbage dumping action detection for real-world surveillance platform. ETRI J. 2019, 41, 494-505. [CrossRef]

112. Hannan, M.A.; Abdulla Al Mamun, M.; Hussain, A.; Basri, H.; Begum, R.A. A review on technologies and their usage in solid waste monitoring and management systems: Issues and challenges. Waste Manag. 2015, 43, 509-523. [CrossRef]

113. Jawad, H.M.; Nordin, R.; Gharghan, S.K.; Jawad, A.M.; Ismail, M. Energy-efficient wireless sensor networks for precision agriculture: A review. Sensors 2017, 17, 1781. [CrossRef]

114. Sohag, M.U.; Podder, A.K. Smart garbage management system for a sustainable urban life: An IoT based application. Internet Things 2020, 11, 100255. [CrossRef]

115. Singhvi, R.K.; Lohar, R.L.; Kumar, A.; Sharma, R.; Sharma, L.D.; Saraswat, R.K. IoT BasedSmart Waste Management System: India Prospective. In Proceedings of the 4th International Conference on Internet of Things: Smart Innovation and Usages, IoT-SIU, Ghaziabad, India, 18-19 April 2019. [CrossRef]

116. Ziouzios, D.; Dasygenis, M. A Smart Bin Implementantion Using LoRa. In Proceedings of the 4th South-East Europe Design Automation, Computer Engineering, Computer Networks and Social Media Conference, SEEDA-CECNSM, Pireus, Greece, 20-22 September 2019. [CrossRef]

117. Lozano, Á.; Caridad, J.; De Paz, J.F.; Villarrubia Gonzalez, G.; Bajo, J. Smart waste collection system with low consumption LoRaWAN nodes and route optimization. Sensors 2018, 18, 1465. [CrossRef]

118. Cerchecci, M.; Luti, F.; Mecocci, A.; Parrino, S.; Peruzzi, G.; Pozzebon, A. A low power IoT sensor node architecture for waste management within smart cities context. Sensors 2018, 18, 1282. [CrossRef] [PubMed]

119. Sheng, T.J.; Islam, M.S.; Misran, N.; Baharuddin, M.H.; Arshad, H.; Islam, M.R.; Islam, M.T. An Internet of Things Based Smart Waste Management System Using LoRa and Tensorflow Deep Learning Model. IEEE Access 2020, 8, 148793-148811. [CrossRef]

120. Karthikeyan, S.; Rani, G.S.; Sridevi, M.; Bhuvaneswari, P.T.V. IoT Enabled Waste Management System Using ZigBee Network. In Proceedings of the 2nd IEEE International Conference on Recent Trends in Electronics, Information \& Communication Technology (RTEICT), Banglore, India, 19-20 May 2017; pp. 2182-2187.

121. Mekki, K.; Bajic, E.; Chaxel, F.; Meyer, F. A comparative study of LPWAN technologies for large-scale IoT deployment. ICT Express 2019, 5, 1-7. [CrossRef]

122. Reis, P.; Caetano, F.; Pitarma, R.; Gonçalves, C. IEcoSys-An intelligent waste management system. Adv. Intell. Syst. Comput. 2015, 353, 843-853. [CrossRef]

123. Aswin Raaju, V.; Mappilllai Meeran, J.; Sasidharan, M.; Premkumar, K. IOT based Smart Garbage Monitoring System Using ZigBee. In Proceedings of the IEEE International Conference on System, Computation, Automation and Networking, ICSCAN, Pondicherry, India, 29-30 March 2019. [CrossRef]

124. Wilson, S.T.; Sebastine, T.K.; Daniel, M.; Martin, V. Smart trash bin for waste management using odor sensor based on IoT technology. Int. J. Adv. Res. Ideas Innov. Technol. 2019, 5, 2048-2051.

125. Rahman, M.W.; Islam, R.; Hasan, A.; Bithi, N.I.; Hasan, M.M.; Rahman, M.M. Intelligent waste management system using deep learning with IoT. J. King Saud Univ. Inf. Sci. 2020. [CrossRef]

126. Asghari, P.; Rahmani, A.M.; Javadi, H.H.S. Internet of Things applications: A systematic review. Comput. Netw. 2019, 148, $241-261$. [CrossRef]

127. Madakam, S.; Ramaswamy, R.; Tripathi, S. Internet of Things (IoT): A Literature Review. J. Comput. Commun. 2015, 3, 164-173. [CrossRef]

128. Ben-Daya, M.; Hassini, E.; Bahroun, Z. Internet of things and supply chain management: A literature review. Int. J. Prod. Res. 2019, 57, 4719-4742. [CrossRef]

129. Sethi, P.; Sarangi, S.R. Internet of Things: Architectures, Protocols, and Applications. J. Electr. Comput. Eng. 2017, $2017,9324035$. [CrossRef]

130. Marques, P.; Manfroi, D.; Deitos, E.; Cegoni, J.; Castilhos, R.; Rochol, J.; Pignaton, E.; Kunst, R. An IoT-based smart cities infrastructure architecture applied to a waste management scenario. Ad Hoc Netw. 2019, 87, 200-208. [CrossRef]

131. Hong, I.; Park, S.; Lee, B.; Lee, J.; Jeong, D.; Park, S. IoT-Based Smart Garbage System for Efficient Food Waste Management. Sci. World J. 2014, 1-13. [CrossRef]

132. Popa, C.L.; Carutasu, G.; Cotet, C.E.; Carutasu, N.L.; Dobrescu, T. Smart city platform development for an automated waste collection system. Sustainability 2017, 9, 2064. [CrossRef] 
133. Indexed, S.; Yerraboina, S.; Kumar, N.M.; Parimala, K.S.; Jyothi, N.A. Monitoring the Smart Garbage Bin Filling Status: An Iot Application. Int. J. Civ. Eng. Technol. 2008, 9, 373-381.

134. Jinila, Y.B.; Alam, M.S.; Singh, P.D. Cloud-Based Scheme for Household Garbage Collection in Urban Areas. In Advances in Big Data and Cloud Computing; Springer: Berlin/Heidelberg, Germany, 2019; pp. 539-546.

135. Ramson, S.R.; Moni, D.J.; Vishnu, S.; Anagnostopoulos, T.; Kirubaraj, A.A.; Fan, X. An IoT-based bin level monitoring system for solid waste management. J. Mater. Cycles Waste Manag. 2021, 23, 516-525. [CrossRef]

136. Soh, Z.H.C.; Husa, M.A.A.-H.; SAbdullah, A.C.; Shafie, M.A. Smart Waste Collection Monitoring and Alert System via IoT. In Proceedings of the IEEE 9th Symposium on Computer Applications \& Industrial Electronics (ISCAIE), Kuala Lumpur, Malaysia, 17-28 April 2019; pp. 50-54.

137. Atayero, A.A.; Williams, R.; Badejo, J.A.; Popoola, S.I. Cloud based IoT-enabled solid waste monitoring system for smart and connected communities. Int. J. Civ. Eng. Technol. 2019, 10, 2308-2315.

138. Shirke, P.S.I.; Ithape, S.; Lungase, S.; Mohare, M. Automation of smart waste management using IoT. Int. J. Civ. Eng. Technol. 2019, $6,414-419$.

139. Hussain, A.; Draz, U.; Ali, T.; Tariq, S.; Irfan, M.; Glowacz, A.; Antonino Daviu, J.A.; Yasin, S.; Rahman, S. Waste management and prediction of air pollutants using IoT and machine learning approach. Energies 2020, 13, 3930. [CrossRef]

140. Chen, G.; Xu, B.; Lu, M.; Chen, N.-S. Exploring blockchain technology and its potential applications for education. Smart Learn. Environ. 2018, 5, 1. [CrossRef]

141. Di Silvestre, M.L.; Gallo, P.; Guerrero, J.M.; Musca, R.; Sanseverino, E.R.; Sciumè, G.; Vásquez, J.C.; Zizzo, G. Blockchain for power systems: Current trends and future applications. Renew. Sustain. Energy Rev. 2020, 119, 109585. [CrossRef]

142. Pilkington, M. Blockchain Technology: Principles and Applications. In Research Handbook on Digital Transformations; Edward Elgar Publishing: Camberley, UK, 2016.

143. Gopalakrishnan, P.K.; Hall, S.J. Behdad, A Blockchain-Based Traceability System for Waste Management in Smart Cities. In Proceedings of the Engineering Technical Conferences \& Computers and Information in Engineering Conference, Online, 17-19 August 2020; p. V006T06A015.

144. Gopalakrishnan, P.K.; Hall, S.J. Behdad, Cost analysis and optimization of Blockchain-based solid waste management traceability system. Waste Manag. 2021, 120, 594-607. [CrossRef] 